\title{
من فلسفة الإبداع إلى إبداع الفلسفة: \\ قراءة في الإنجاز الفكري لطه عبد الرحمن إلى الرعن
}

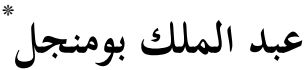

$$
\begin{aligned}
& \text { الملخص }
\end{aligned}
$$

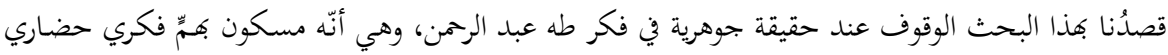

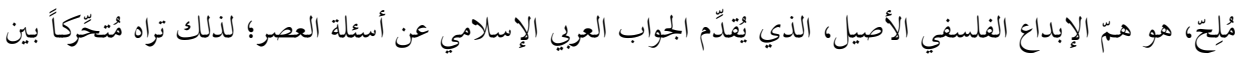

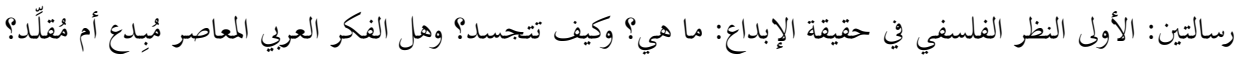

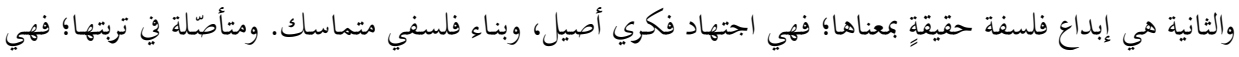

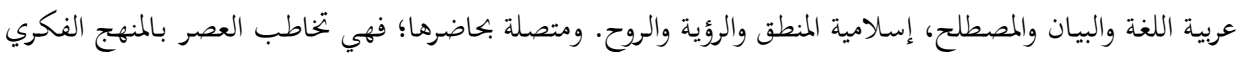

$$
\begin{aligned}
& \text { الذي يناسبه، وتعالج مشكلاته بالمنطق الفلسفي الذي يفهمه. } \\
& \text { الكلمات المفتاحية: طه عبد الرمن، إبداع الفلسفة، فلسفة الإبداع، طبيعة الإبداع، الفكر العربي الإسلامي. }
\end{aligned}
$$

Abstract

From the philosophy of creativity to creative philosophy: A reading on the Intellectual accomplishment of Taha Abdurrahman

The aim of this article is to understand the essence of Taha Abdurrahman's thought. This philosopher is haunted by an urgent intellectual and civilizational concern; it is the original philosophical creativity which provides Arabic Islamic response to contemporary questions. He has been moving between two messages: The first one is the philosophical perspective of creativity; what is it? How does it materialize? Is contemporary Arabic though creative or imitative? The second message is the creative production of a real philosophy; an original intellectual ijtihad, and coherent philosophical structure; a philosophy that is rooted deeply in its natural soil; Arabic in language and terminology, Islamic in its vision and spirit; addresses contemporary time with proper intellectual method, and solves its problems using the appropriate logic.

Key terms: Taha Abdurrahman, Philosophy of creativity, Creative philosophy, Nature of creativity, Arabic Islamic thought.

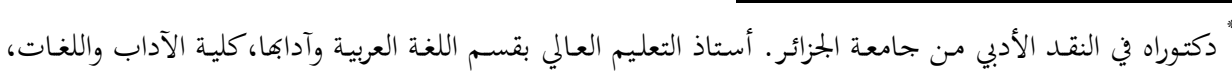

$$
\begin{aligned}
& \text { جامعة سطيف ب- الجزائر. البريد الإلكتروني: abumindjel@yahoo.fr }
\end{aligned}
$$

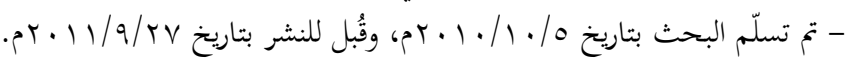




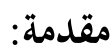

منذ قرن ونيّف والخطاب الفكري العربي يحمل طموحات النهضة والحداثة واللحاق بالركب الحضـاري، ويرفع شعارات التجديـد والتنوير والإبـداع والأصـالة والحريـة. دعـوات تُرسَل إلى كل مكان ويُشار إليها في كل مناسبة، وشعارات تُرفَع في كل خطاب وكتاب وكتاب.

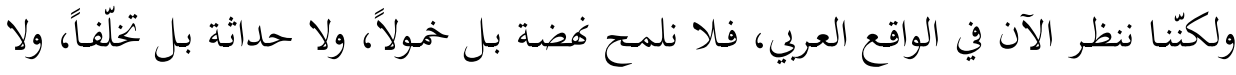

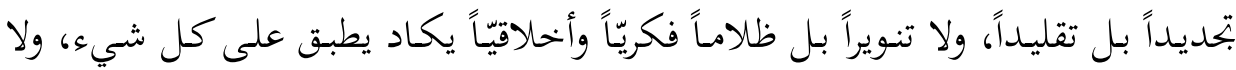

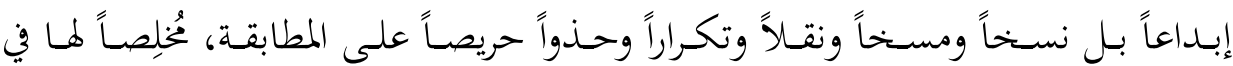

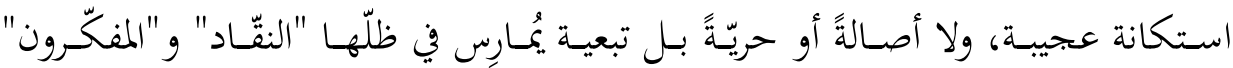

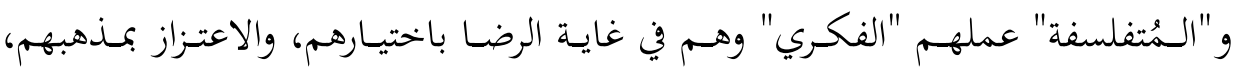
والاقتناع بأفم يسلكون المسلك الصحيح على طريق الإبداع والحداثة والتنوير في طريق اللحاق بالركب الحضاري! ماذا حصل؟ وأين الخلل ؟ أيكون "المفكرون" العرب على حقّ، ويكون مذهبهم على صواب، ولكنّ الطريق بعيد، ولا بُدَّ من الصبر، ومـن مواصلة الضرب في هذا الطريق إلى

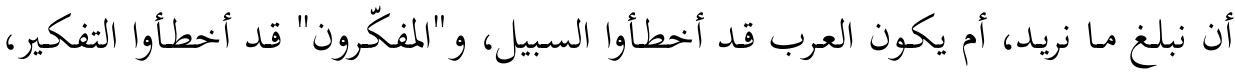
والرافعون دعوى التجديد والإبداع قد ناقضوا الدعوى واستكانوا لدعة التقليد؟ لم أجدد في الخطابات والكتابات المعاصرة جواباً، عن هذا السؤال، أوفى وأشفى من

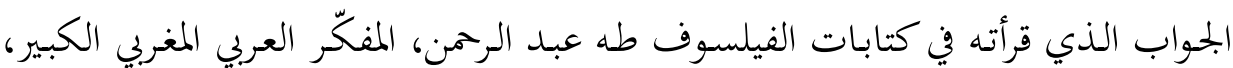

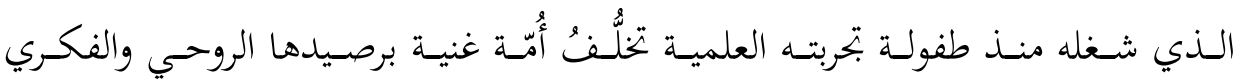

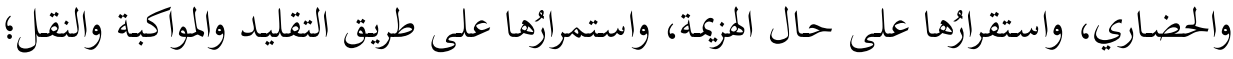
فجمع أطراف موهبته الفكرية، وحشد أشتات طاقاته العقلية وعدّته المعرفية، ودفع همّته في طريق الكشف عن أسباب التخلّف والتقليد والعجز، وسبيل الخروج من حال التبعية إلى حـال الاستقلال والحرية، ومـن حـال التقليد والعجز إلى حـال الإبـاع والقـدرة، ومـن حال التقمّص والمطابقة إلى حـال التميّز والخصوصية؛ بمشروع فكري فلسفي متماسكك

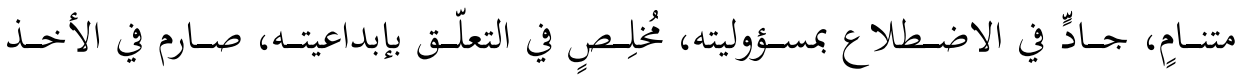


بأسباب علميته وعقلانيته، يتعقّب مواقع الإظلام ومواضع الالتباس؛ ليكشف الحقائق،

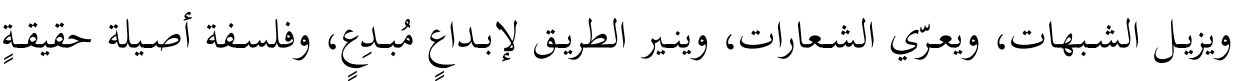

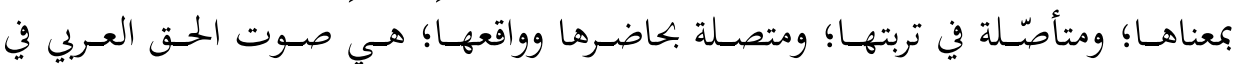
الاختلاف الفلسفي، وصورة الجواب الإسالامي عن أسئلة العصر.

لقد توالت بحوث طه عبد الرحمن وكتبه في سبيل استكمال هـذا المشروع الفلسفي

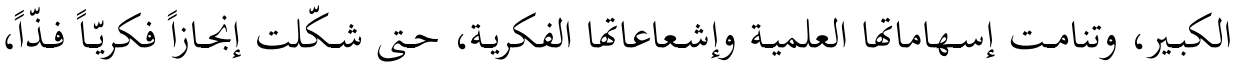
يلفت انتباه أهل النظر والفكر والبحث عن الحقيقة والحرية؛ ببنيته الفلسفية المتماسكة،

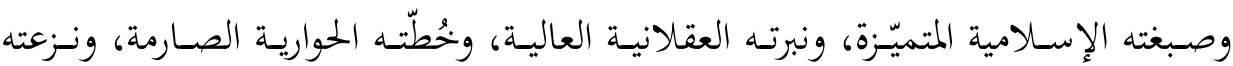
الإنسانية الخالصة، ومنظومته المصطلحية الأصيلة. وهو إبحاز لم ينل -على علو قيمته، ووضوح تميّزه وإضـافته- مـا يستحقق مس الاهتمـام والاحتفـاء، ومسن المدارسـة والمناقشـة؛ لأسباب تتصل بواقع الحياة الثقافية العربية السائدة في إقامتها على تقليد الفلسفة الغربية،

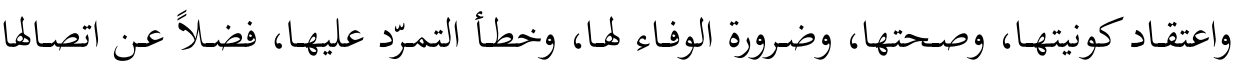
بمضمون هذا الإبنحاز الفكري مـن حيـث هجومه القوي على مدّّعي التفلسف والإبـداع والحداثـة مـن "الـمُتفلسفين" العـرب المعاصرين، ومـن حيـث متانـة بنائه العلمي وصـلابة أسسه المنهجية، بحيث يصرف عن الاحتفاء به إنكارُ مضمونه المتمرّد على تقليد الفلسفة الغربيـة، ويصـرف عـن التصــي لـه بالنقـــ العجـزُ عـن مضـارعة متانته العلميـة وصـلابته المنهجية.

إنّ هذا المفكّر الفيلسوف يتحّرك في جُحلّ إبحازاته الفكرية، بين رسالتين عظيمتين:

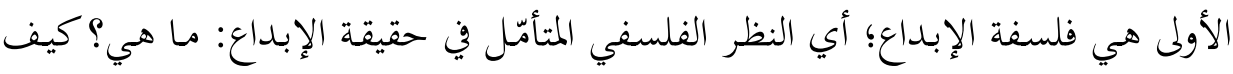

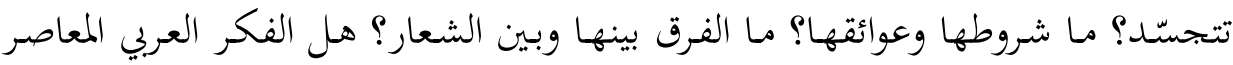

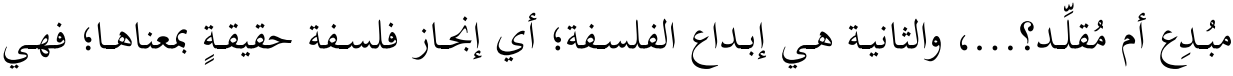
اجتهاد فكري أصيل، وهي بناء فلسفي متماسك. ومتأصّلة في تربتها؛ فهي عربية اللغة

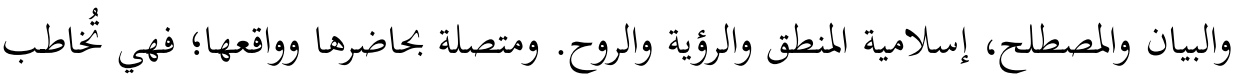

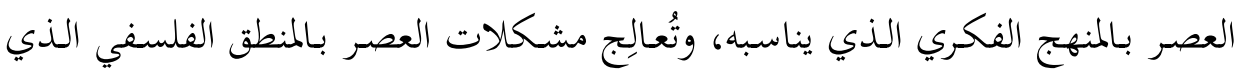




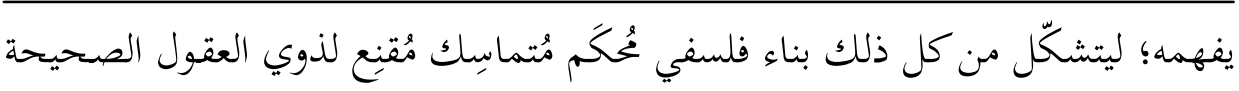
والقلوب الباحثة عن الحقيقة.

\section{أولاً: فلسفة الإبداع}

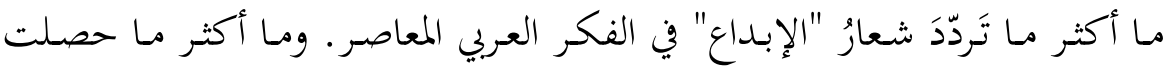

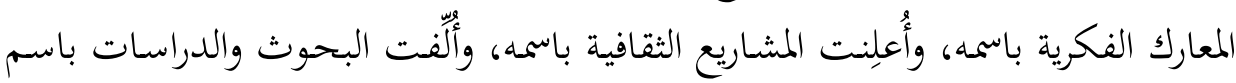

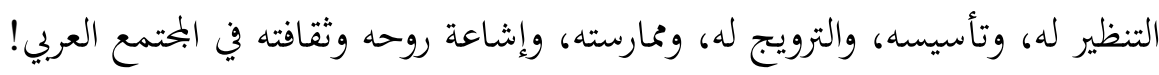

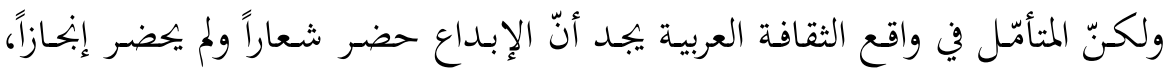

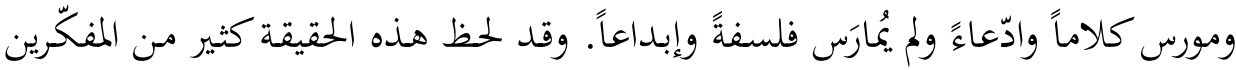

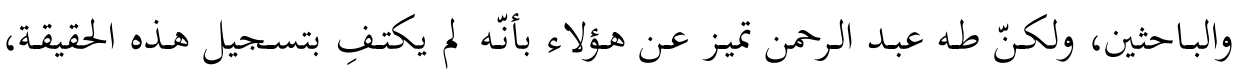

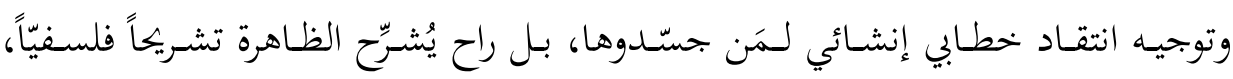

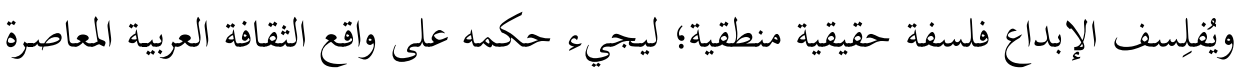

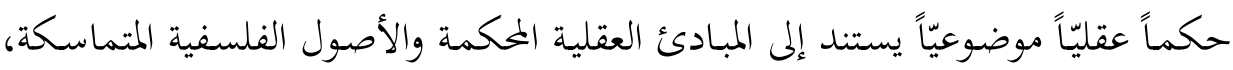

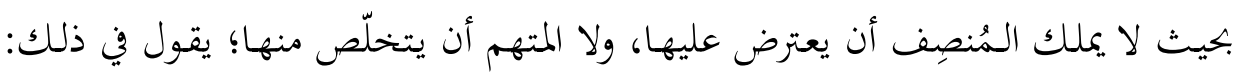

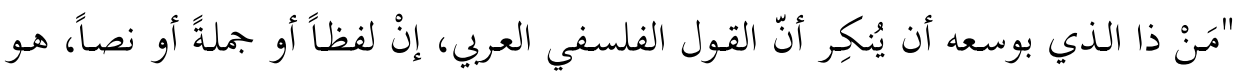

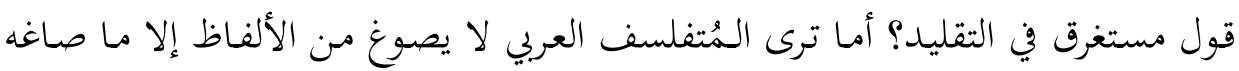

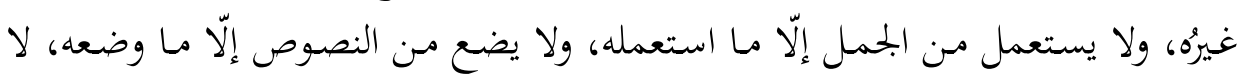

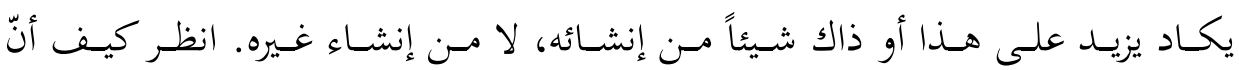

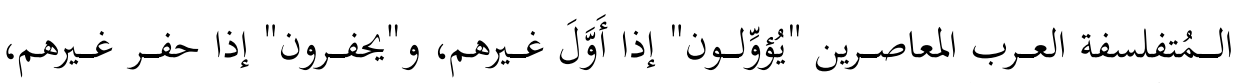

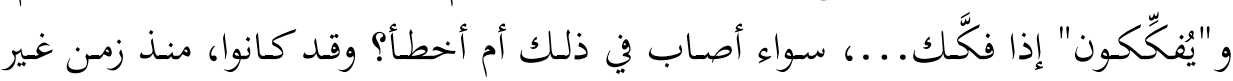

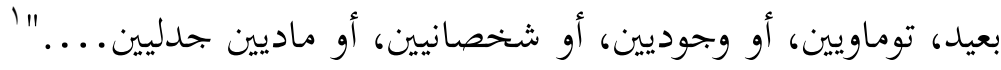

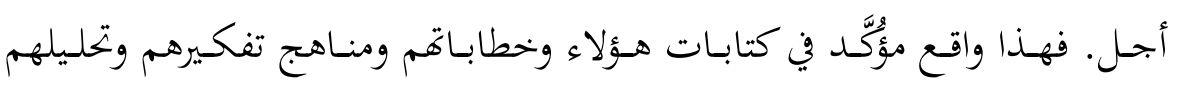

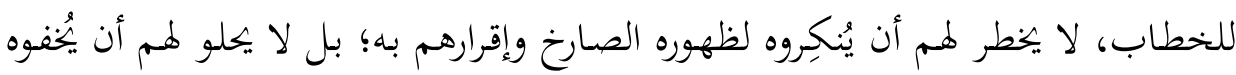

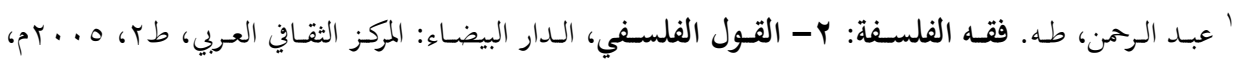




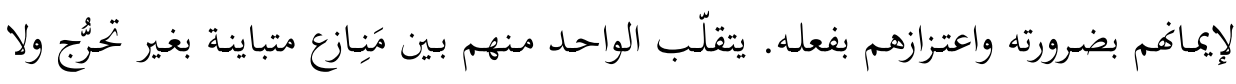

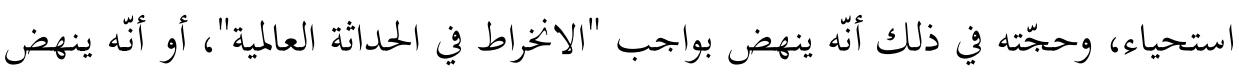

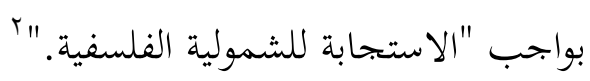

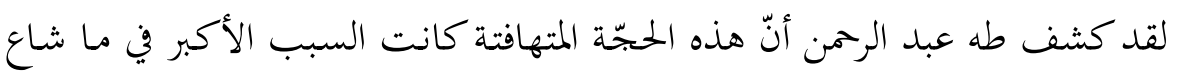

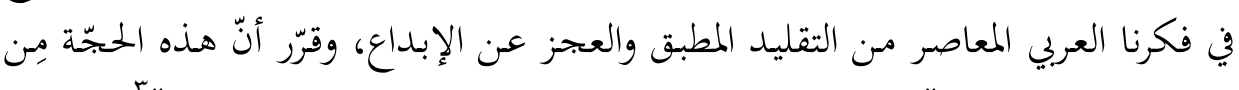

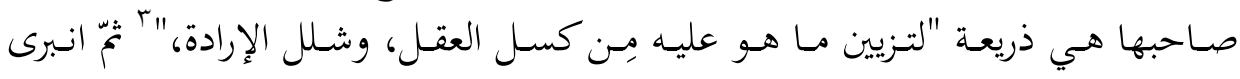

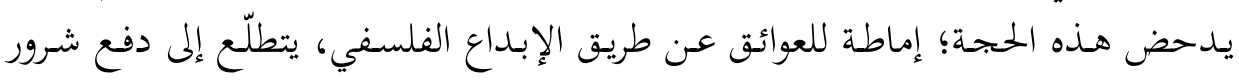

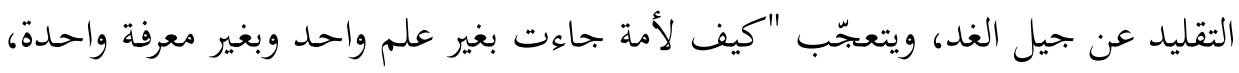

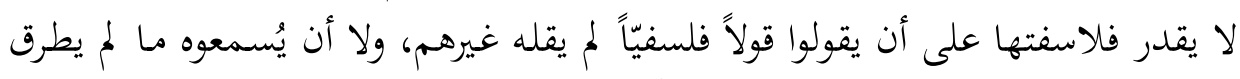

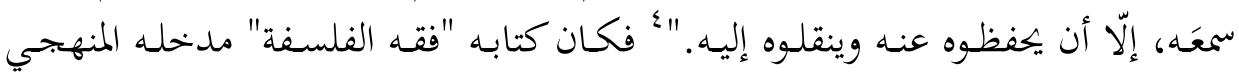

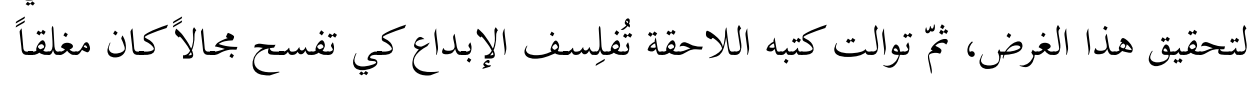
لإلابداع الفلسفة.

\section{ا ـ الاعتراض شرط الإبداع:}

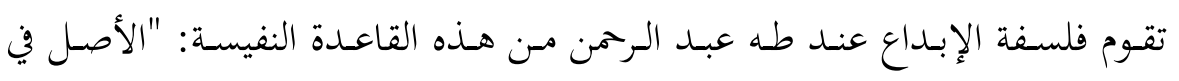

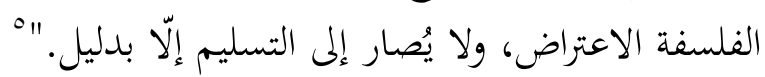

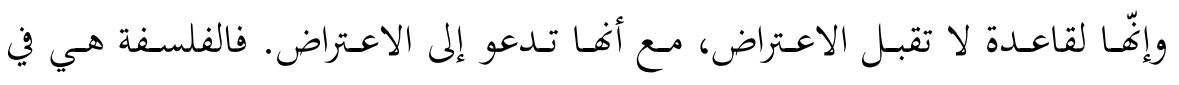

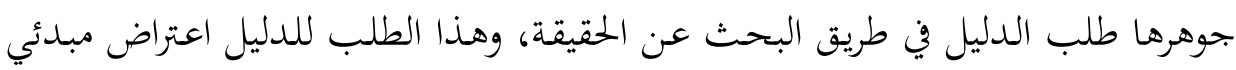

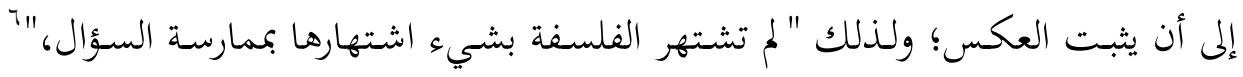

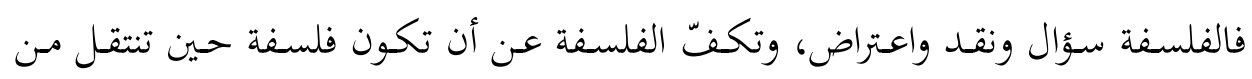
الانتقاد إلى الاعتقاد. vو

$$
\begin{aligned}
& \text { r المرجع السابق، صזr ا. }
\end{aligned}
$$

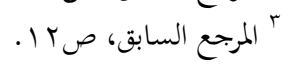

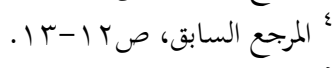

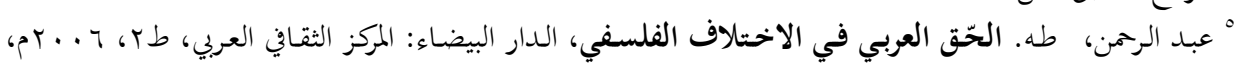

$$
\text { " " المرجع السابق، صـ صـ ال. }
$$




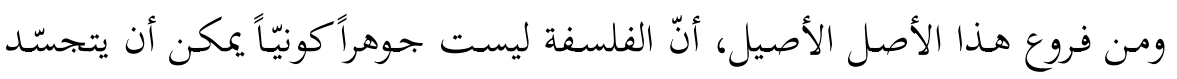

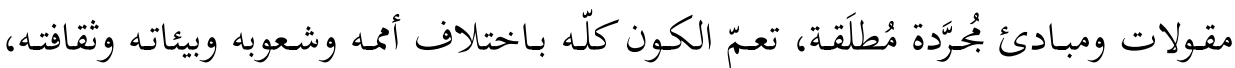

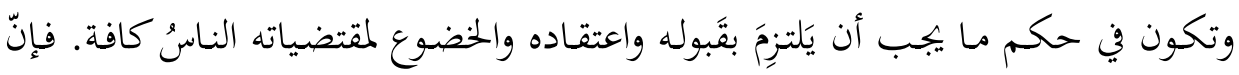

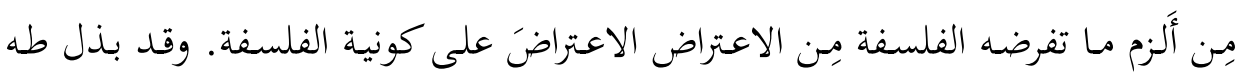

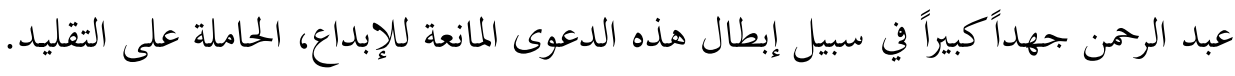

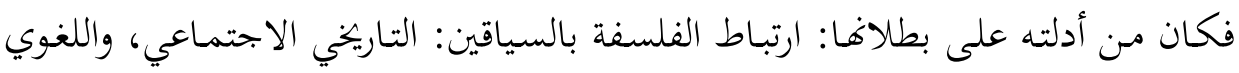

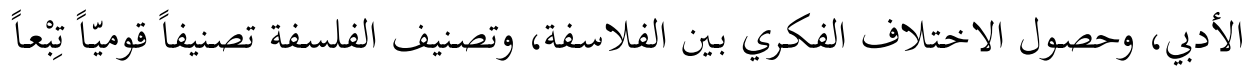
لهذا الاختلاف، وذلك الارتباط؛ فهناك فلسفة يونانية، وأخرى فرنسية، وأخرى ألمانية...

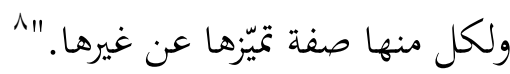

وكان من الأدلة أيضاً أنّ الكونية قول بالفكر الواحد والواقع الواحد. والفكر الواحد

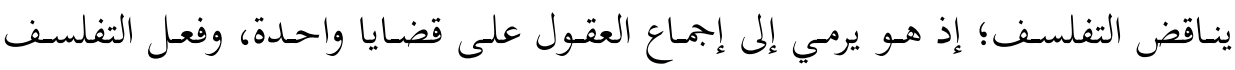

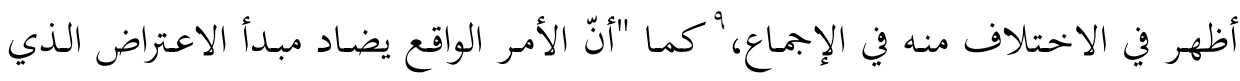

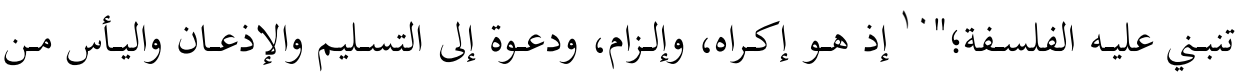

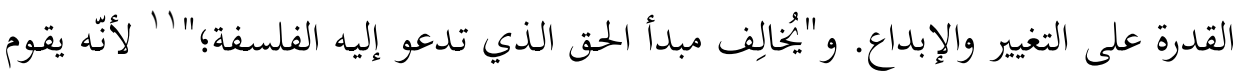
على طلب المصلحة للطرف الأقوى الذي يطلب حصول هذا الإذعان.

وكـان منها كـذلك أنّ القـول بالكونيـة ينبني على معادلة استـلالية فاسـدة، هي

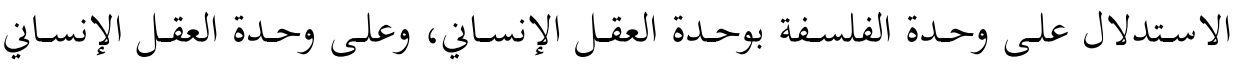

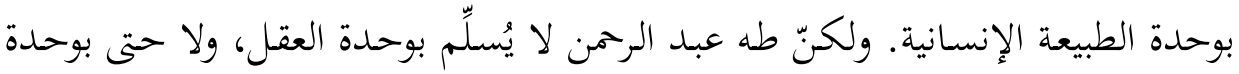

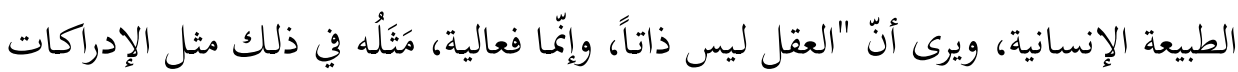

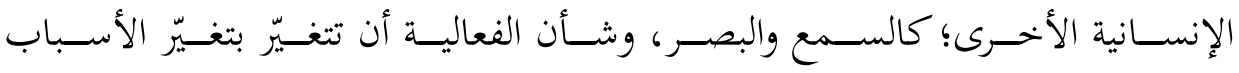

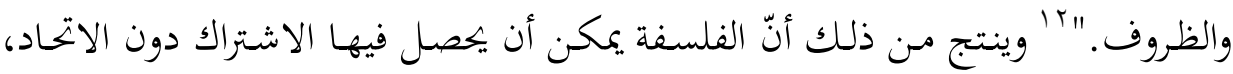

$$
\begin{aligned}
& \text { ^ المرجع السابق، صبه صـــــ. }
\end{aligned}
$$

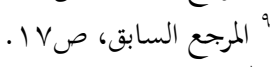

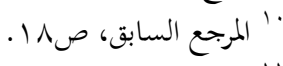

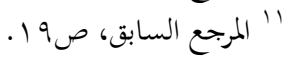

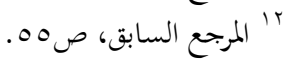




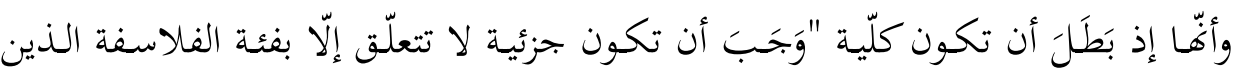

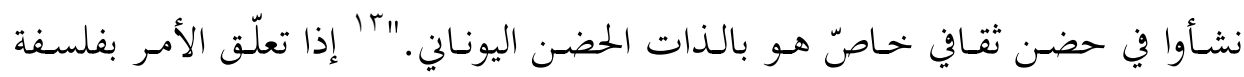
الإغريق، والحضن "الأوروبي" إذا تعلّق الأمر بالفلسفة الغربية، والحضن بـ "الألماني" إذا تعلّق

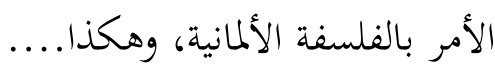

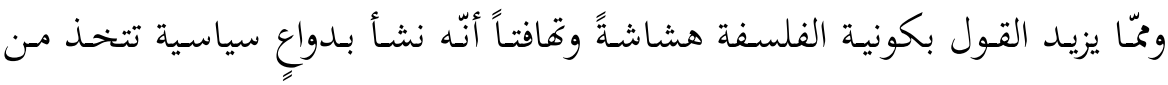
التنظير للمركزية الأوروبية والعالمية الفلسفية ذريعة للهيمنة الثقافية والسياسية والاقتصادية. وقد دلّ تمحيص المسار التاريخي للفلسفة الغربية على أنّ ما يُدعى فلسفة بإطلاق إنّا هو

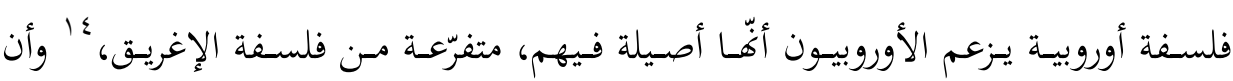

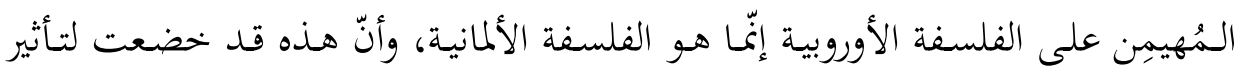
يهـودي واسـع، وأنّ هـا التهويـد قـد أسـلكه مسـلكاً سياسيّاً لتحقيـق طموح الصـهيونية العالمية، وأنّ هذا النفوذ اليهودي أدّى "إلى خلق بيئة فلسفة عامّة موجّهـة بمعالم القومية

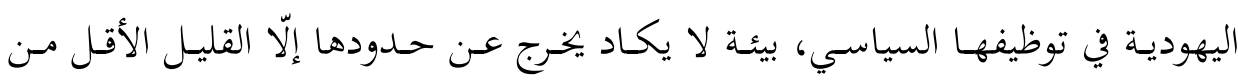

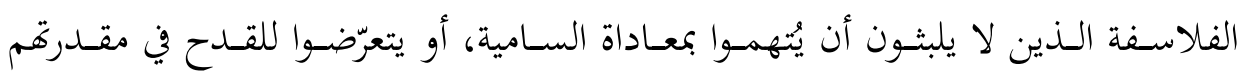

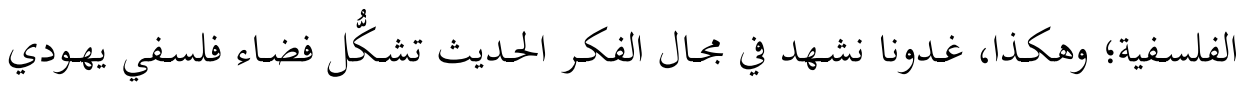
عالمي، يندمج فيه غير اليهودي اندماج اليهودي فيه، عن قصد أو عن غير قصد." "أوهو

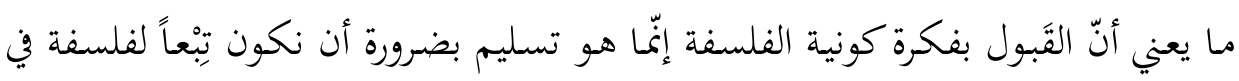
الحياة مُشربة بالنزعات اليهودية، ومُوجَّهة للمصلحة اليهودية، وخادمة للطموح الفكري والسياسي اليهودي.

إنّ أولى خطـوات الإبـاعاع أن يُؤْين الإنسـان بـأنّ إنسـانيته مرهونـة بحريتـه، وحريتـهـ

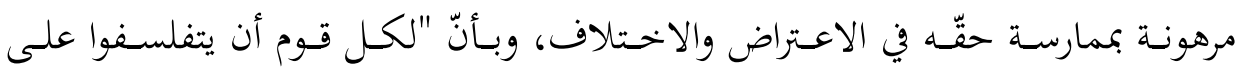
مقتضى خصوصيتهم الثقافية، مع الاعتراف لسواهم بذات الحقق، بحيـث يجـب أن ينشأ

$$
\begin{aligned}
& \text { "ا' المرجع السابق، ص7ه }
\end{aligned}
$$

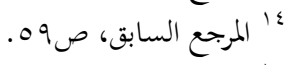

$$
\begin{aligned}
& \text { • } 1 \text { المرجع السرجعابق، صباته صه. }
\end{aligned}
$$




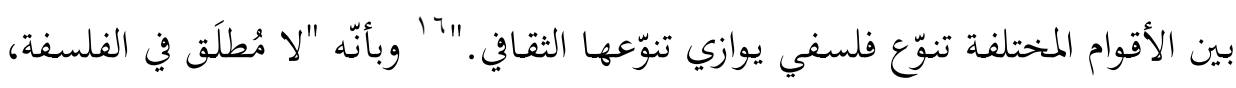

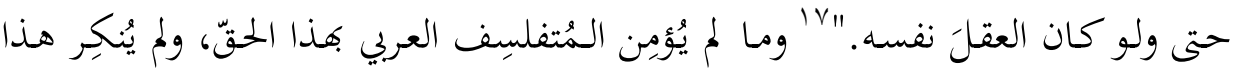

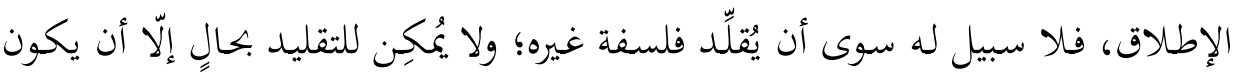
نقيض الإبداع.

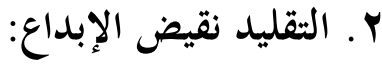

بناءً على هذه المبادئ الفلسفية، ينظر طه عبد الرحمن في المُنجز العربي المعاصر من

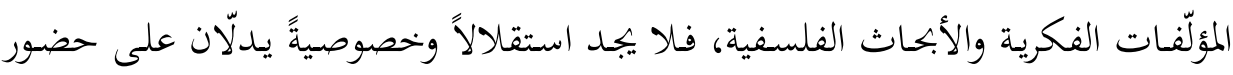

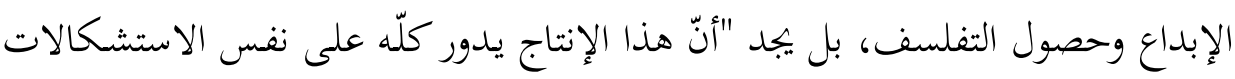

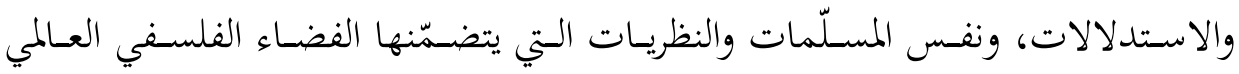

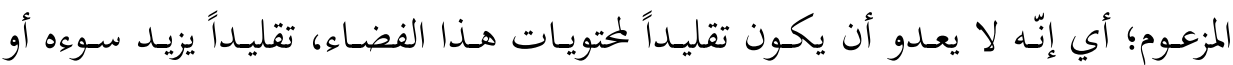

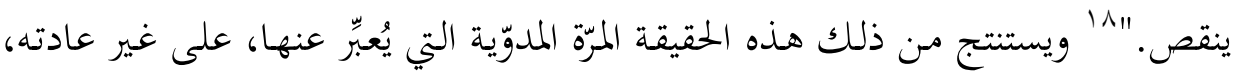

كهذه اللغة الإنشائية المنفعلة الثائرة:

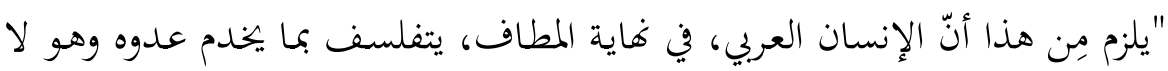

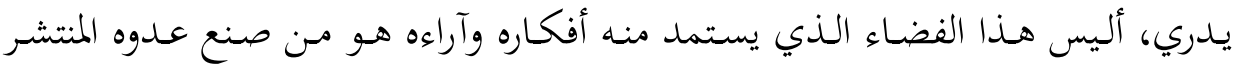

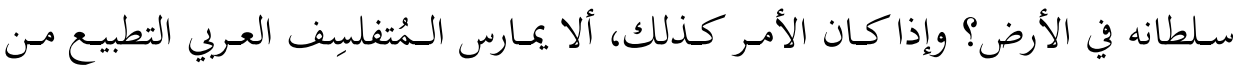

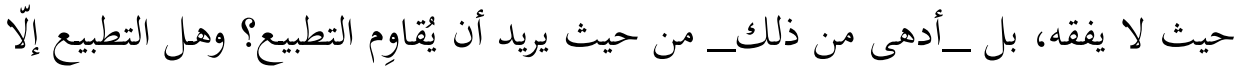

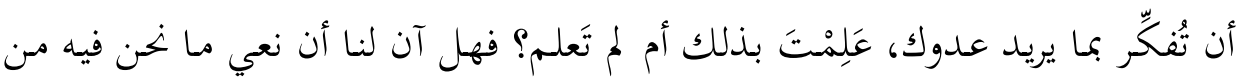

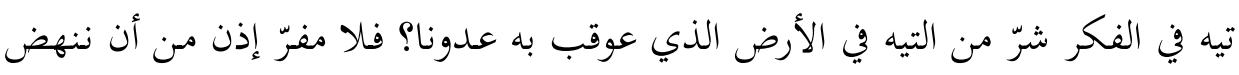

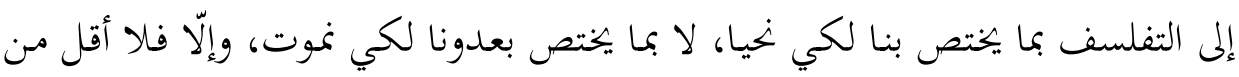

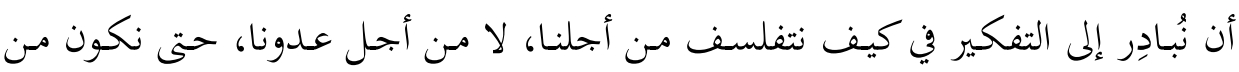

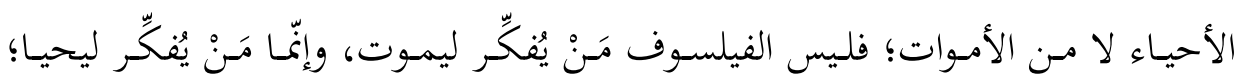

$$
\begin{aligned}
& \text { "17 المرجع السابق، صابل. }
\end{aligned}
$$

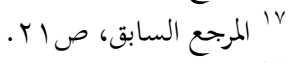

$$
\begin{aligned}
& \text { '^ 'المرجع السابق، صلب، صلr. }
\end{aligned}
$$




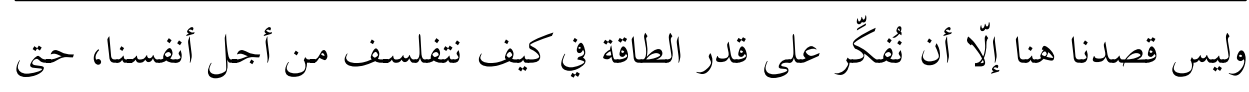

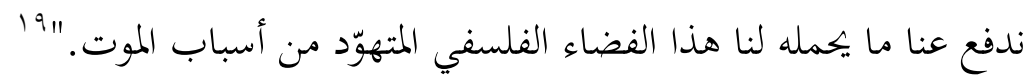

فواقع الفكر العربي المعاصر لا ينحصر فساده في بحرّد سكونيته وتقليديته وعجزه عن

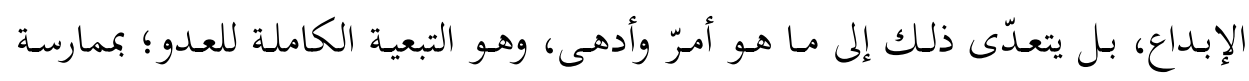

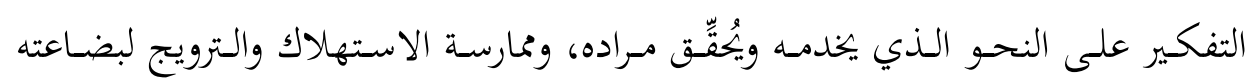

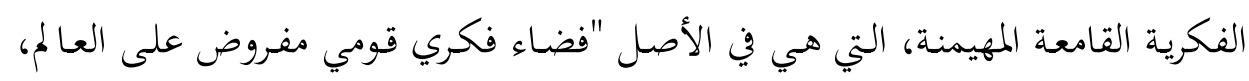

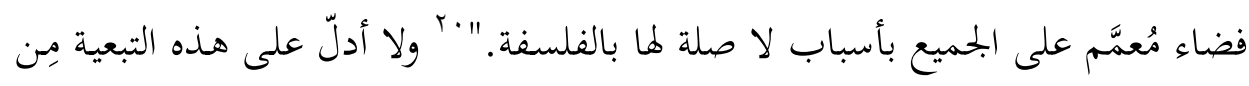

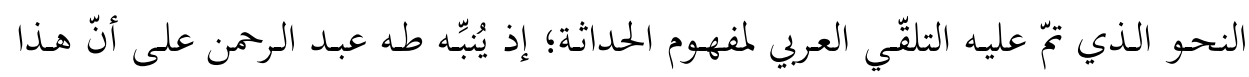

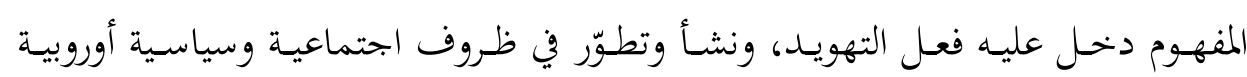

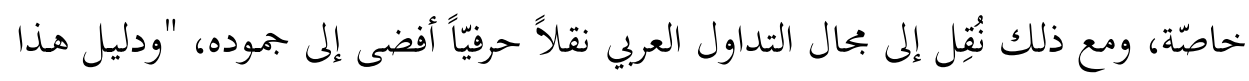

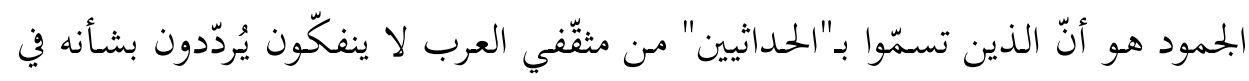

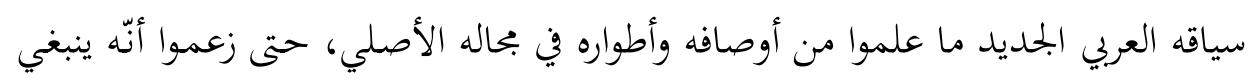

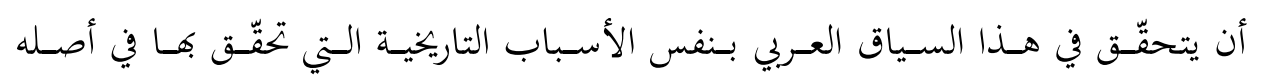

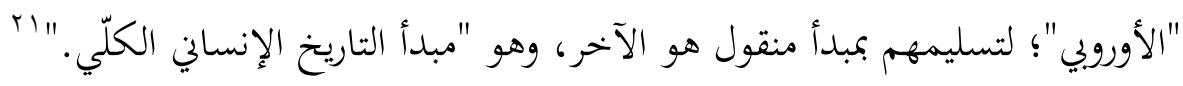

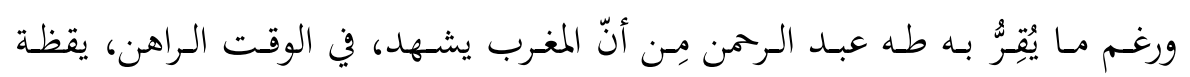

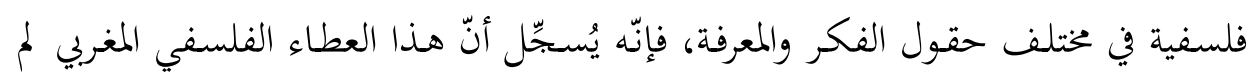

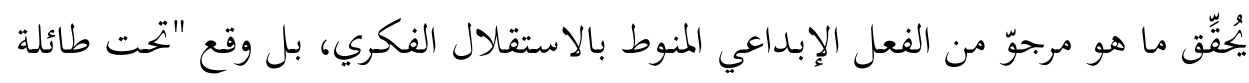

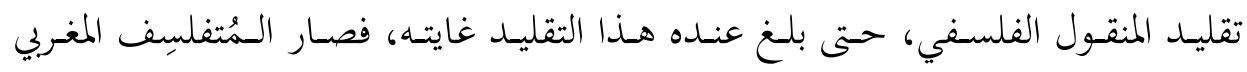

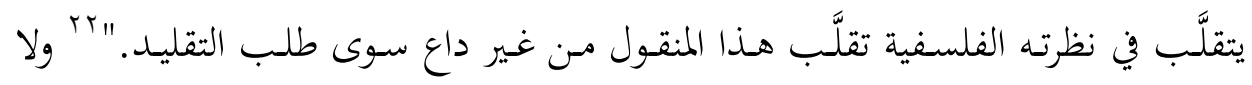

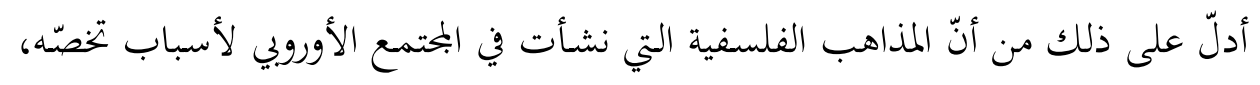

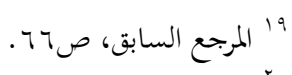

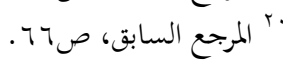

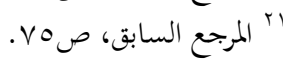

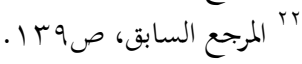




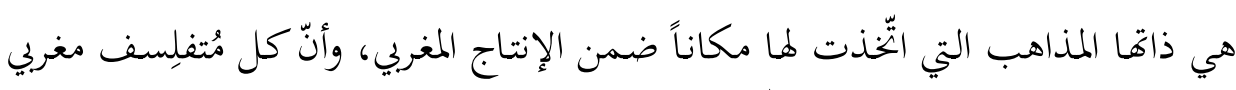

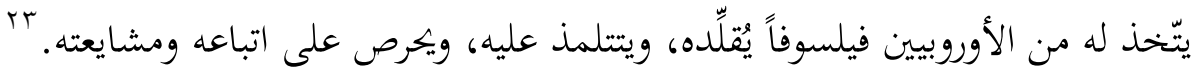
وإذا كان هذا هو حال الفلسفة المغربية، وهي توصف باليقظة ويُعترَف لها بالنشاط، فكيف هو حال الفلسفة العربية عموماً? هال الفران لقد لحظ طه عبد الرحمن أنّ المفكّر العربي، وهو يرفع شعار التحديث والتنوير، لم

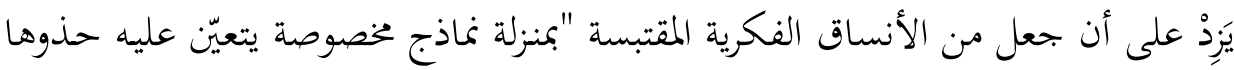

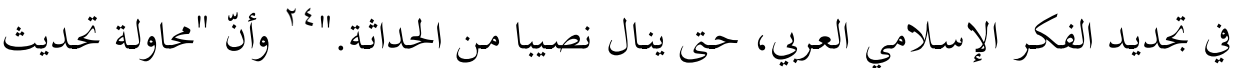

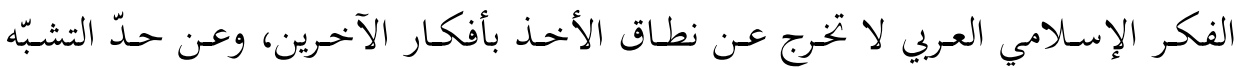

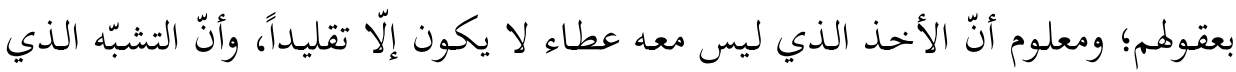

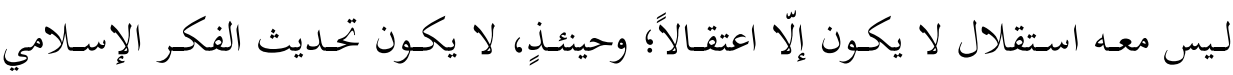

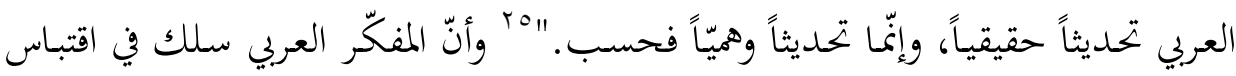

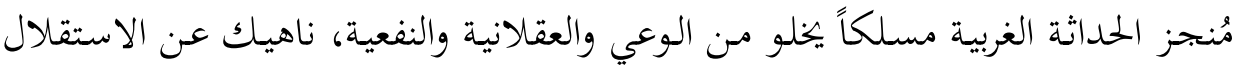

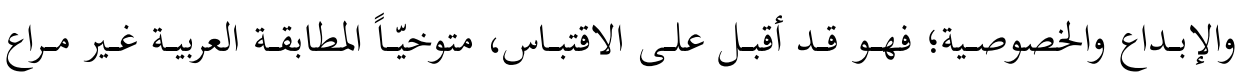

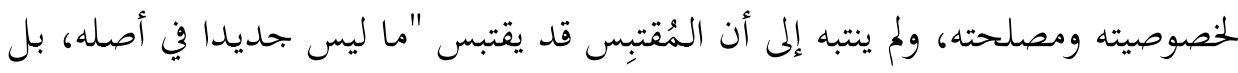

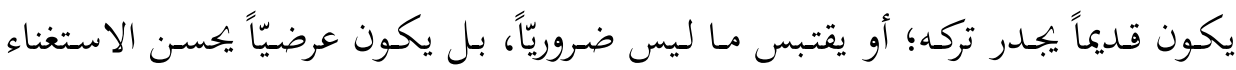

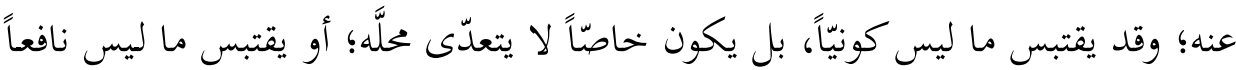

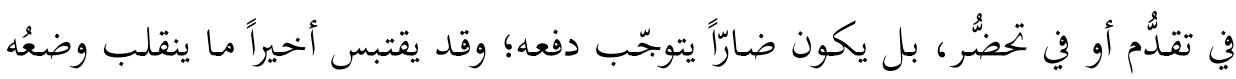

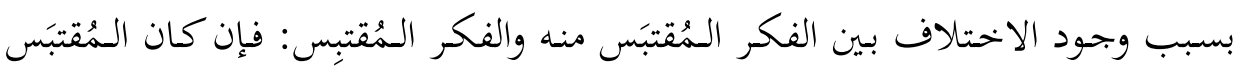

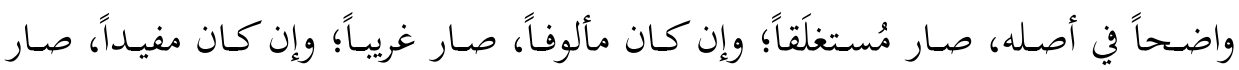

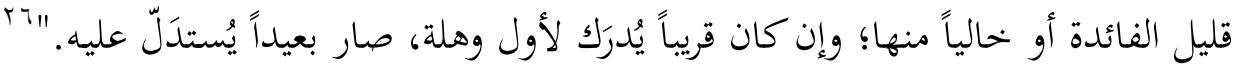

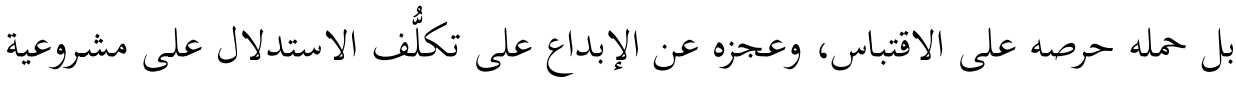

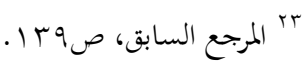

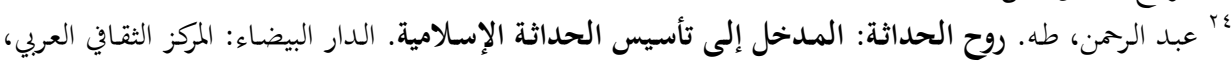

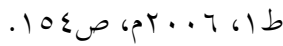

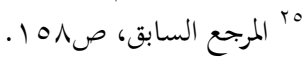

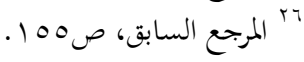


اقتباسه بطريق المقايسة المتعسيّفة التي توهـه المطابقة الكاملة في دواعي الإصلاح الديني، وشروط النهضة، ومبادئ التنوير والعقلانية، بل وفي الفصل بين الدين والسياسة، وتقديم

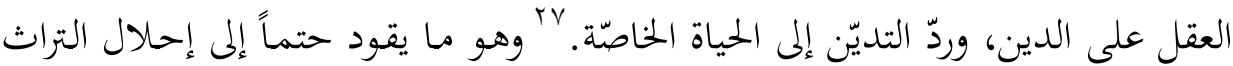

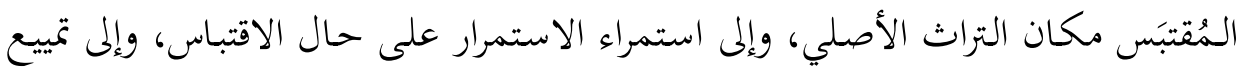
الهوية في فاية المطاف، حين ينظر المُقتتبس إلى الذات بعين الغير، وينظر إلى الغير بعين الغير كذلك. الغويك.

وذلك الذي حصل فعلاً في القراءات الحداثية للقرآن الكريم؛ إذ أصرّ أصحاب هذه

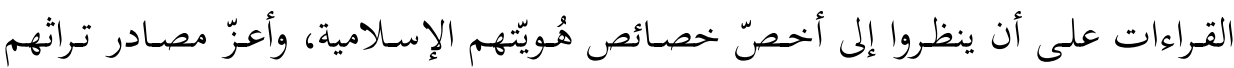

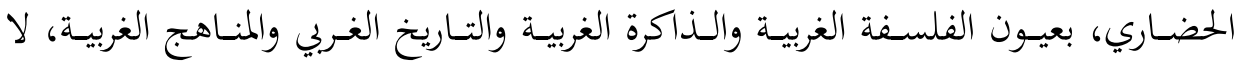

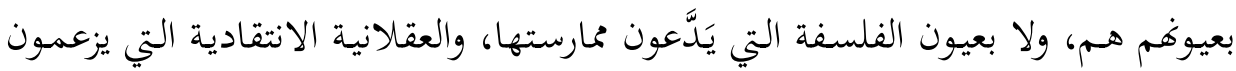

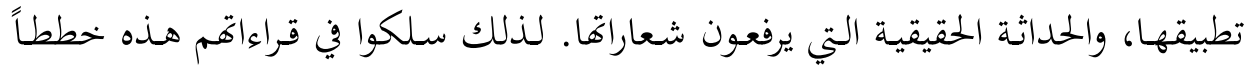
تهدف إلى المطابقة التامّة مع الخصوصية الغربية؛ وهي التأنيس (أو الأنسنة)، والتعقيل (أو

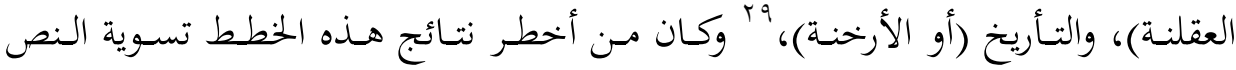
القرآي بالنص البشري، وبتريده من صفة القدسية والتعالي، ثمّ إخضاعه لمختلف المناهج

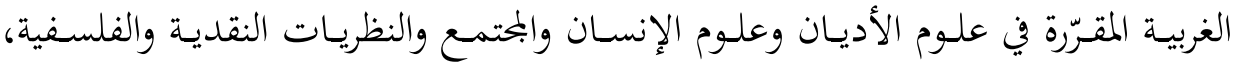

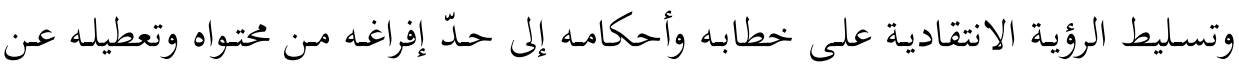
وظيفته.

وما كحان ذلك، في ميزان الحداثة كما يتصوّرها طه عبـد الرحمن، إلّا لأنّ أصحاب هذه القراءات "لم يمارسوا فيها الفعل الحداثي في إبداعيته، ولا انطلقوا فيه من خصوصية تاريخهم، بقدر ما أعادوا إنتاج الفعل الحداثي كما حصل في تاريخ غيرهم، مُقلِّدين أطواره وأدواره؛ ويتجلّى هذا التقليد في كون خططهم الثلاث المذكورة مُستمدَّة من واقع الصراع الـذي خاضـه "الأنواريـون" في أوروبـا مـع رجـال الكنيسـة، والـذي أفضى بهـم إلى تقريـر مبادئ ثلاثة أُنزلت منزلة قوام الواقع الحداثي الغربي.

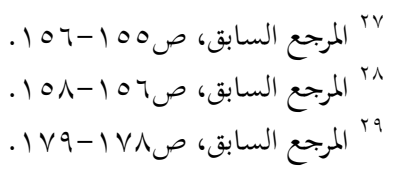


أوهلا، مقتضاه أنّه يجبـب الاشتغال بالإنسان، وترك الاشتغال بالإله؛ وبفضل هـذا

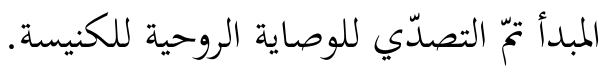

والثاني، مقتضاه أنّه يجب التوسّل بالعقل، وترك التوسّل بالوحي؛ وبفضل هذا المبدأ تمّ التصدّي للوصاية الثقافية للكنيسة.

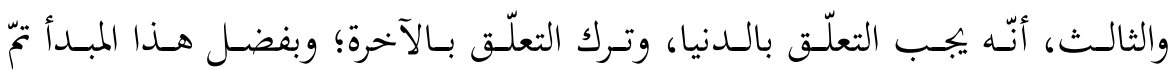
التصدّي للوصاية السياسية للكنيسة."•rاله

واضح أنّ الخطط الثلاث التي وضعها هؤلاء "الحـداثيون" العرب مأخوذة مـن هذه

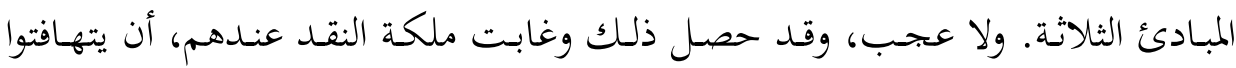

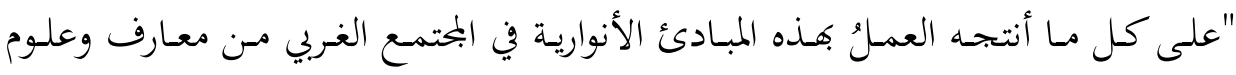

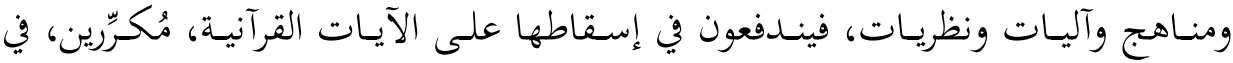

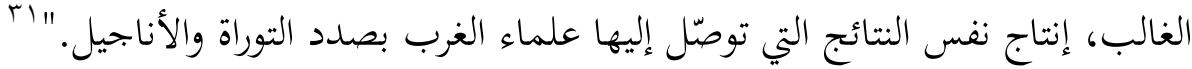

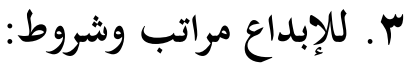

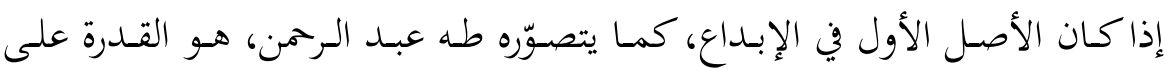

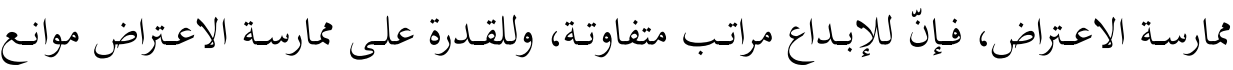

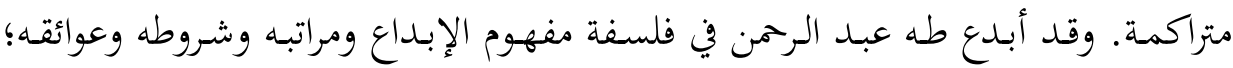

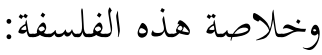

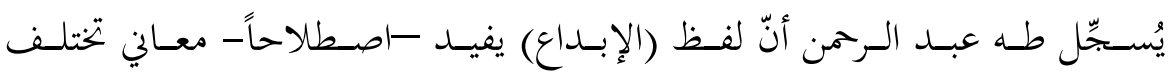

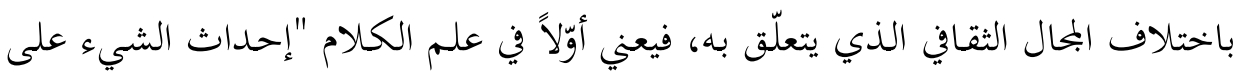

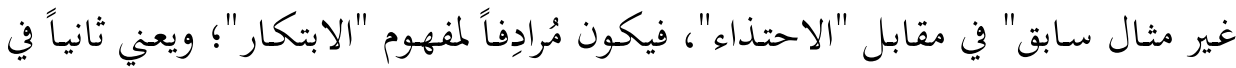

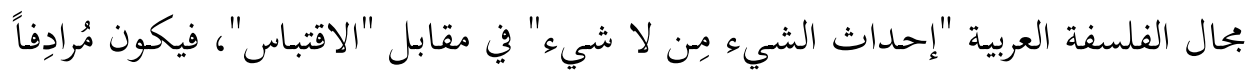

$$
\begin{aligned}
& \text { " المرجع السابق، ص1/19. . }
\end{aligned}
$$

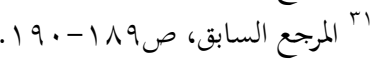


لمفهوم "الاختراع"؛ ويعني ثالثاً في بحال الأدب "إحداث عمل فنّ" في مقابل "الانتحال"،

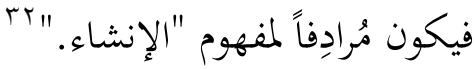

يستفيد طه مِن هـذه المـدلولات الاصطلاحية الثلاثنة للإبـداع، وهـي: "الابتكـار"، و "الاختراع"، و "الإنشاء"، فيأخذ بها جميعاً، ويجعلها مراتب للإبداع مترقية من الأدنى إلى الأعلى، ثمّ يشرع في فلسفة الإبداع انطلاقاً من السؤال عن كيفية فتح الابتكار والاختراع والإنشاء في ممارستنا الفلسفية. وحين يشرع في الجواب عن مثل هذا السؤال يسلك طريقاً

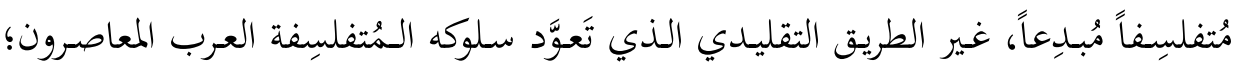
طريق الخوض في الأسباب الموضوعية والشروط الخارجية للإبداع. إنّه يعترض على القول بأن المُتفلسِف العربي سيتمكّن من الإبداع حين "يتفاعل مع أحداث عصره، ويستوعب الَّب تحدّيات محيطه وتثـل مسؤولياته، ويتمثّل أبعاد وضعه التاريخي"، وحسين "يوجد في وسط تتوفر فيـه الإمكانـات الماديـة الكافيـة، وتزدهـر فيـه المؤسسـات العلميـة المختلفـة"، وحـين

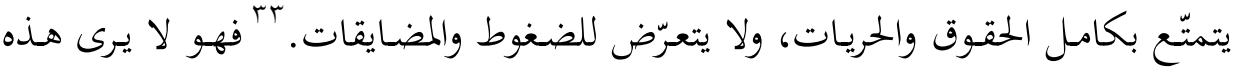
الشـروط كافيـة في حصول الإبـاع، ولا حتى ضـرورية في وجـود الإبـاعاع، بـل يراهـا فرعية بالقياس إلى شرط الإبداع الحقيقي الذي يصوغه على هذا النحو: "تُشترَط في الإبداع -

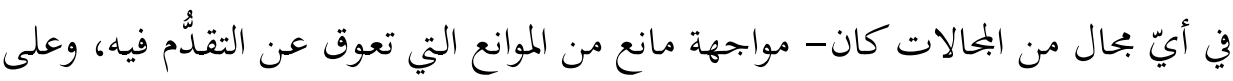

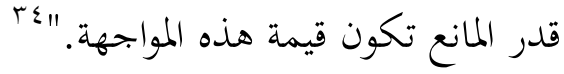
وبعـد أن يميزز طـه الإبـاع الإلهي الـذي يجصـل عـن كمـال في الإرادة، مسن الإبــاع

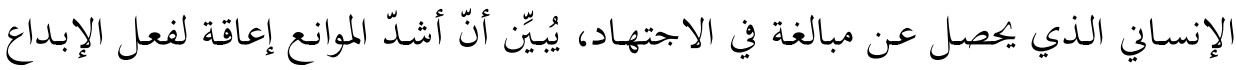

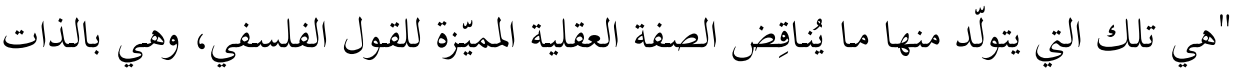

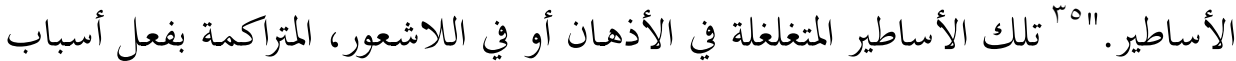
قديمة مُتجدِّدة، أساسها إضفاء القداسة على القول الفلسفي الغربي؛ قديمه، وحديثه.

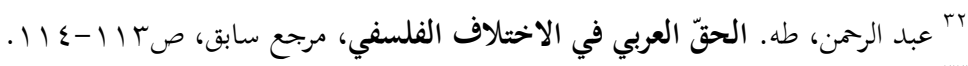

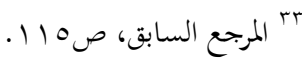

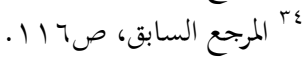

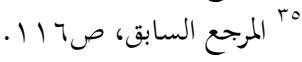




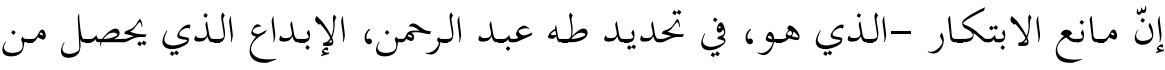

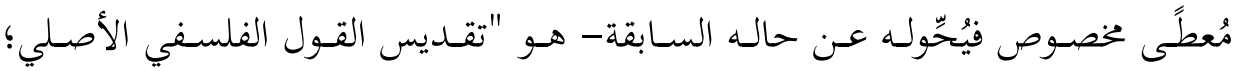

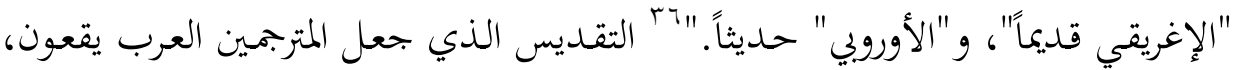

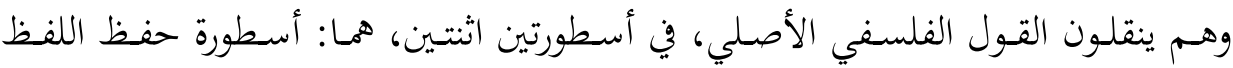

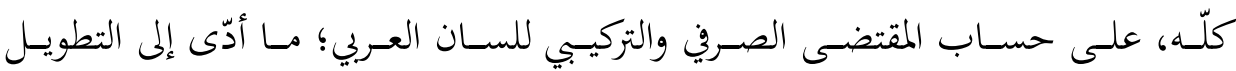

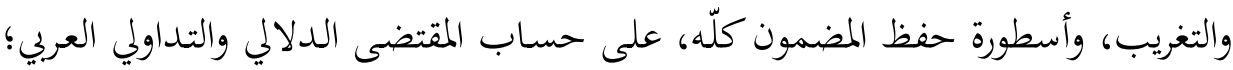

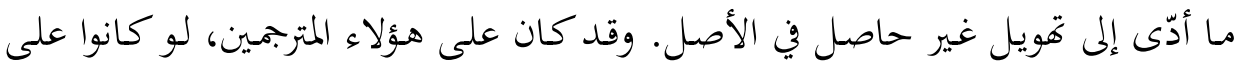

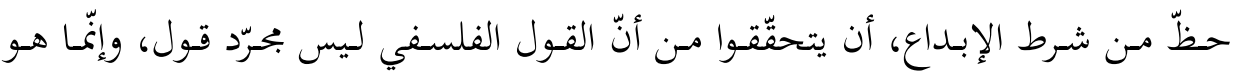

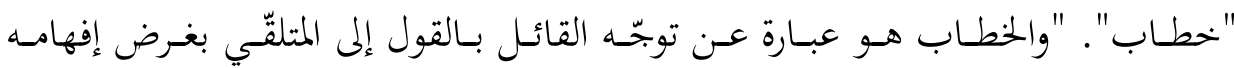

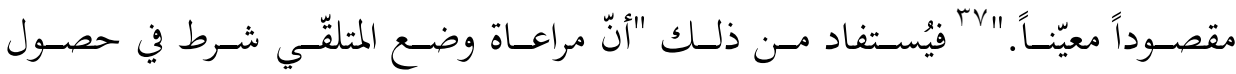

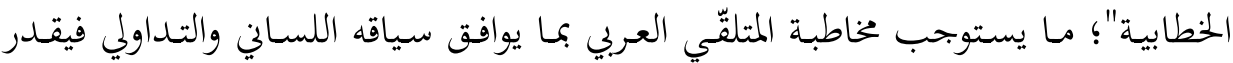

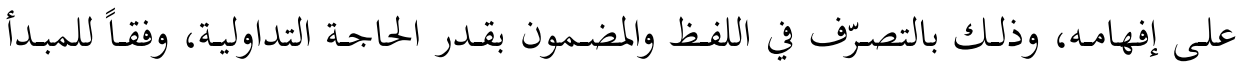

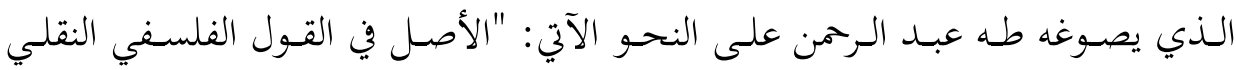

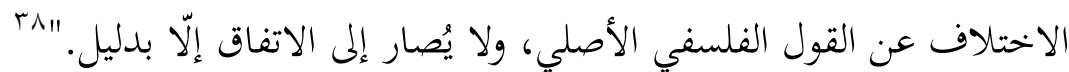

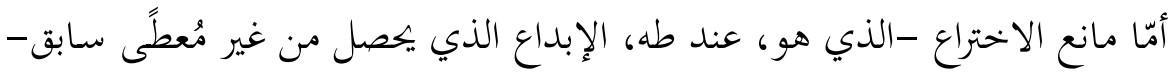

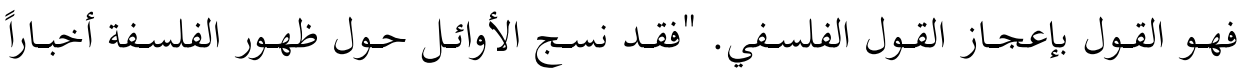

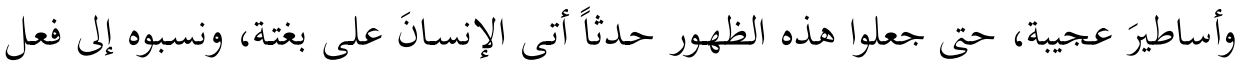

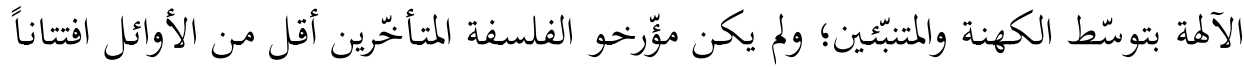

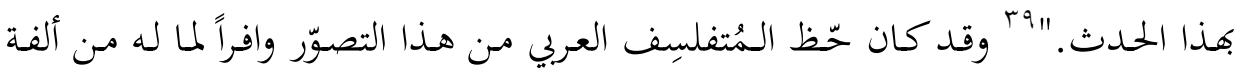

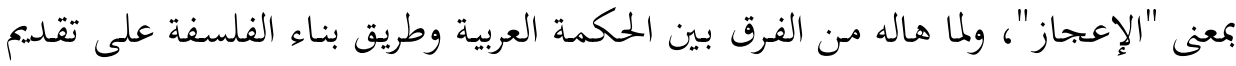

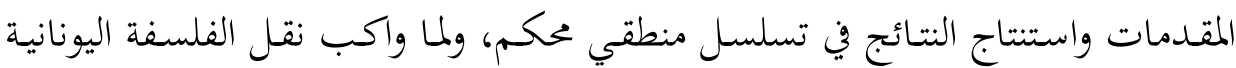

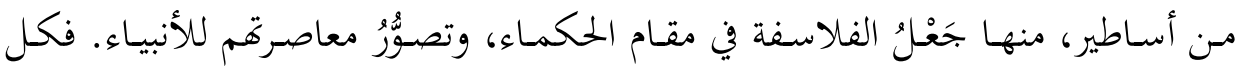




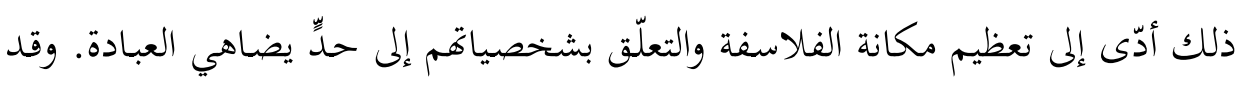

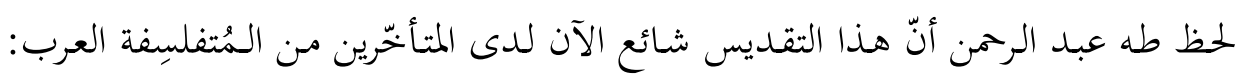

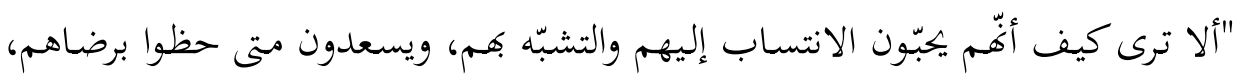

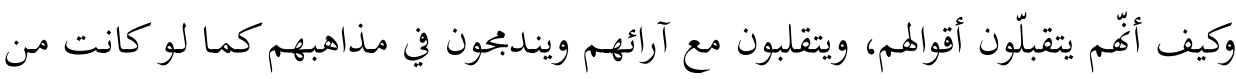

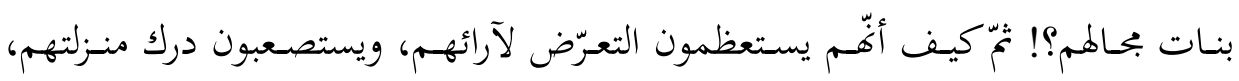

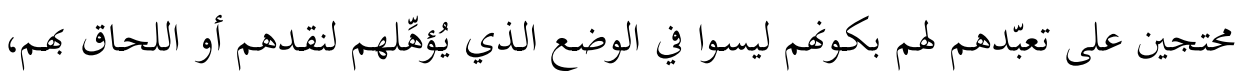

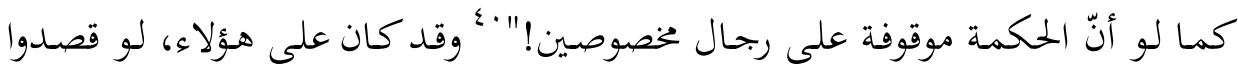

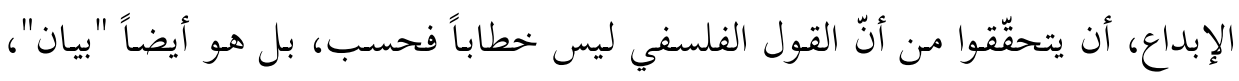

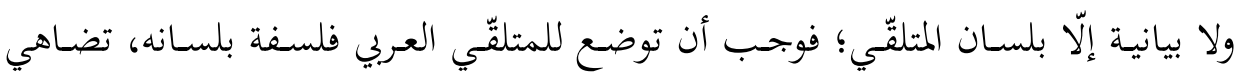

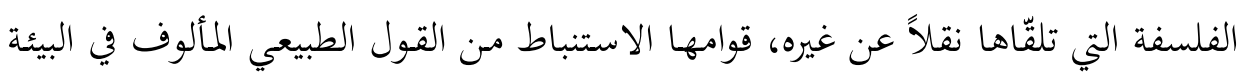

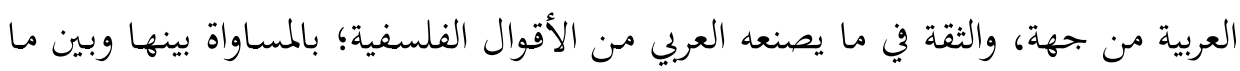

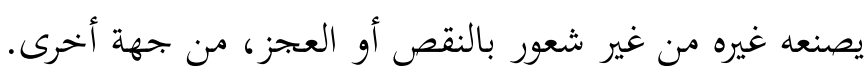

ومانع الإنشاء -الذي هو، عند طه عبد الرحن، الإبداع الذي فيه صنعة؛ أي طريقة

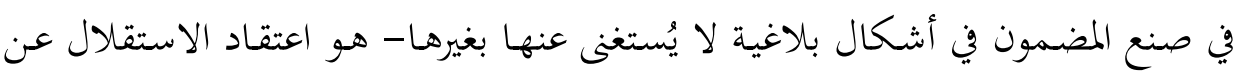

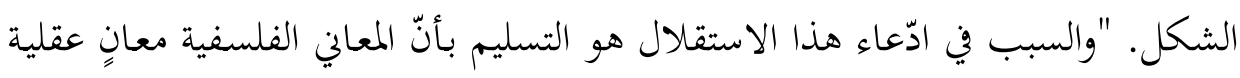

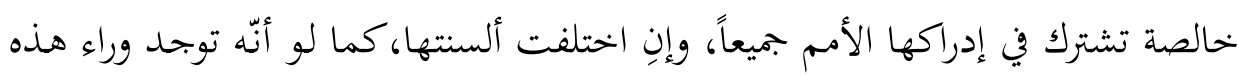

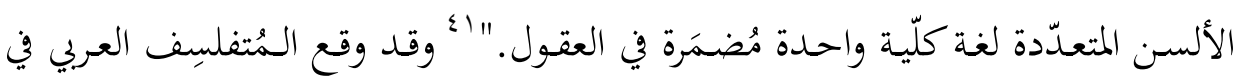

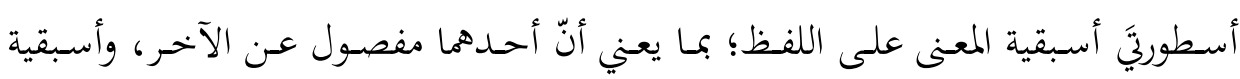

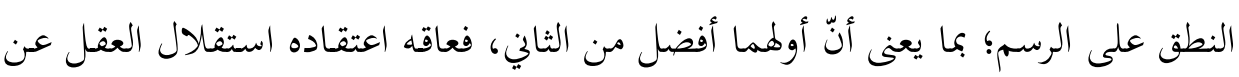

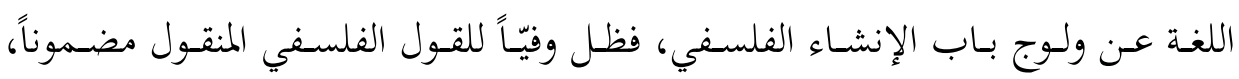

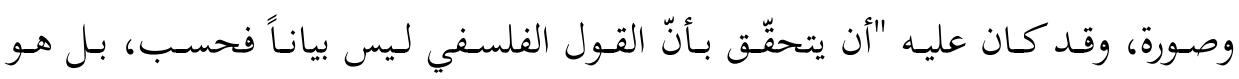

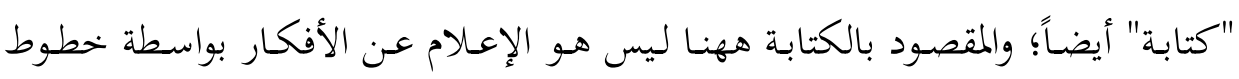

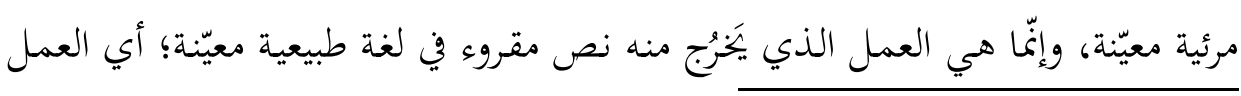

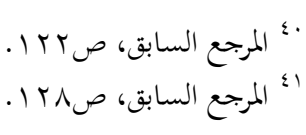




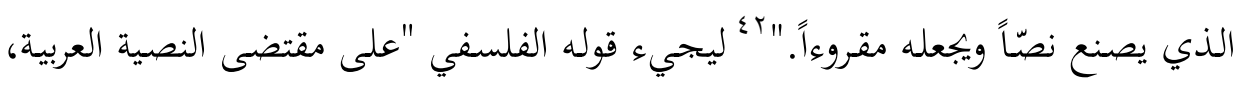
فيُكتَب بأشكالها الباغية الخاصّة بها، لا على مقتضى نصية غيرها، حتى ولو كان نقلاً

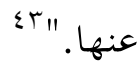

ويبـدو أنّ طـه عبــ الرحمن يعسير اهتمامـاً بالغـاً بـدور اللغـة في الإجابـة عـن سؤال

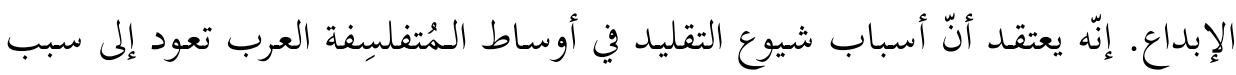

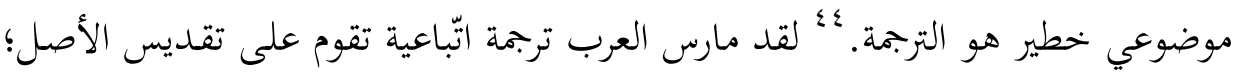

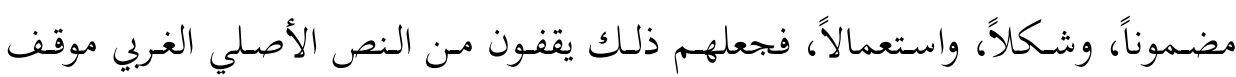

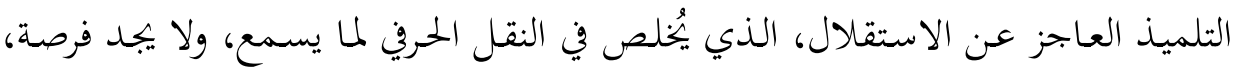
بل رغبة، في السؤال، أو الاعتراض، أو الاجتهاد الذي يسير به في طريق الإبداع. إنّ طه عبد الرحمن يثور على هذه التقليدية المستكينة، ويجتهـد وسعه في أن يجيء

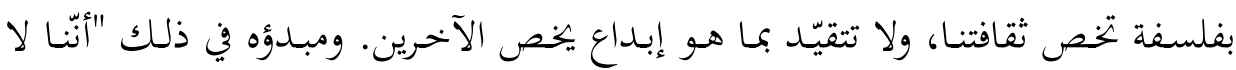

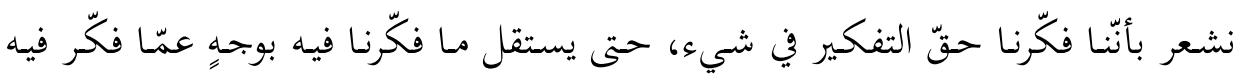

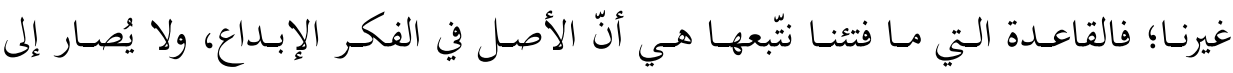

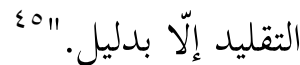

ثانياً: إبداع الفلسفة

يتردّد الجههد الفكري لطه عبد الرحمن بين فلسفة الإبداع وإبداع الفلسفة. وإذ فرغنا

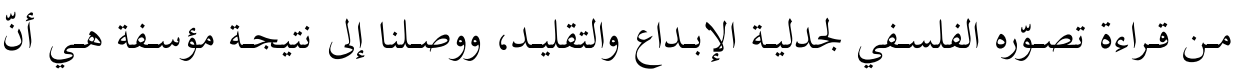

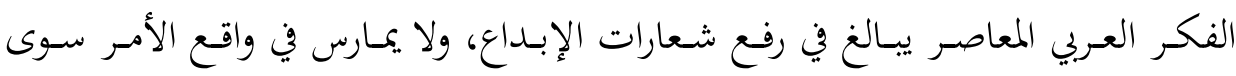

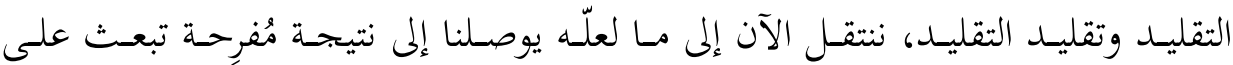
التفاؤل بمستقبل إبداعي واعد للفكر العربي والثقافة العربية.

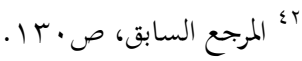

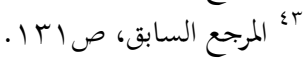

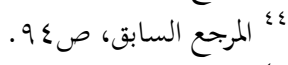

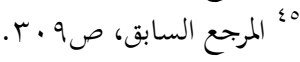




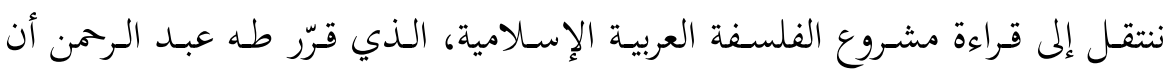

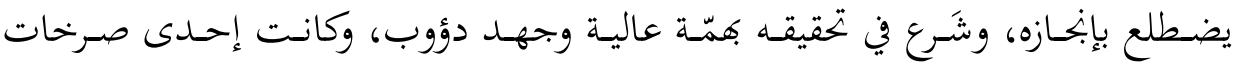

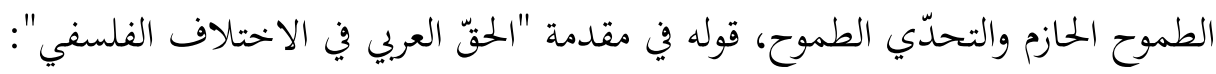

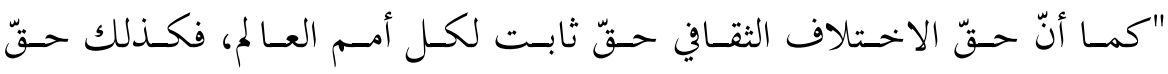

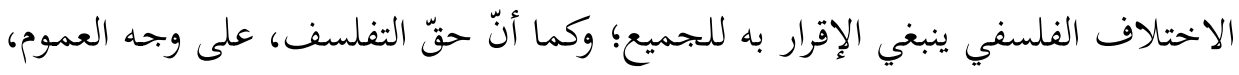

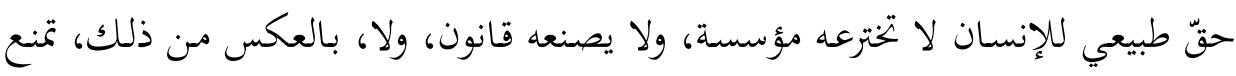

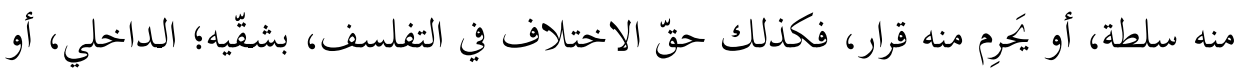

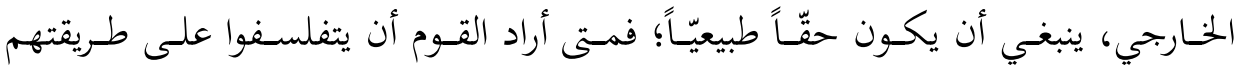

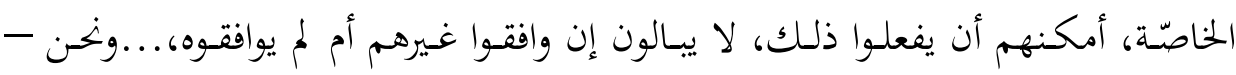

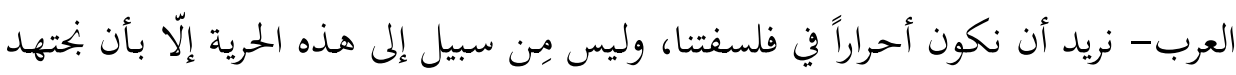

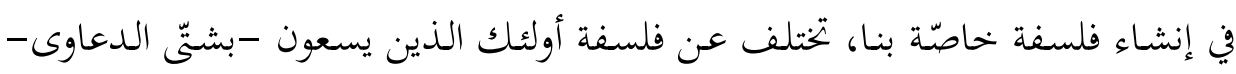

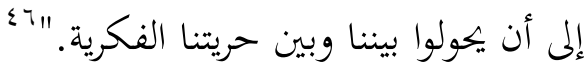

لقد آمن طه عبد الرحمن بأنّ "الأصل في الفكر الإبـاع، ولا يُصار إلى التقليد إلّا

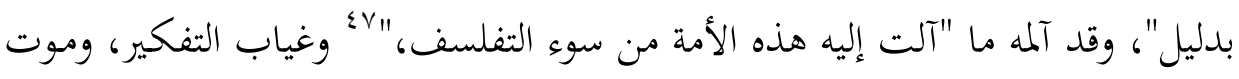

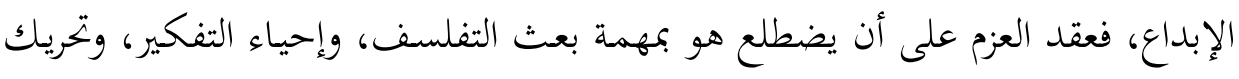

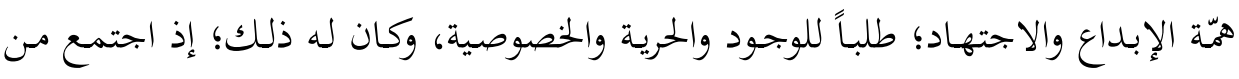

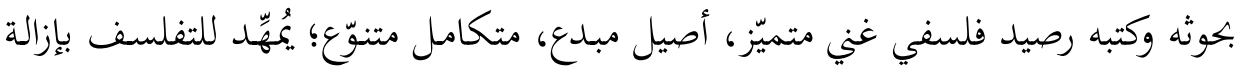

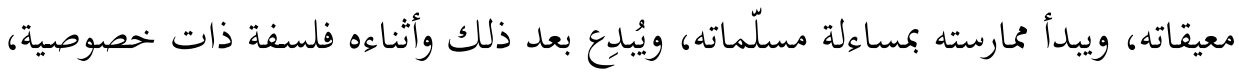

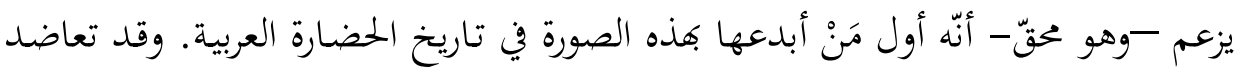

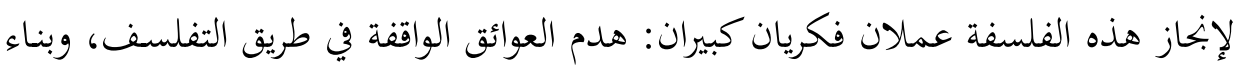
التفلسف بخصوصية عربية إسلامية. 


\section{1ـ إماطة العوائق عن طريق التفلسف:}

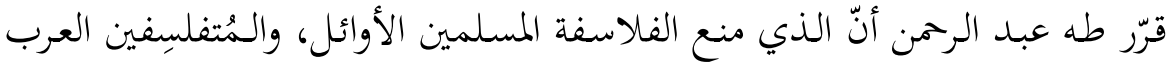

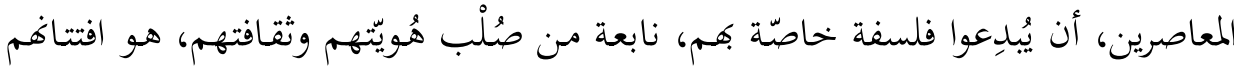

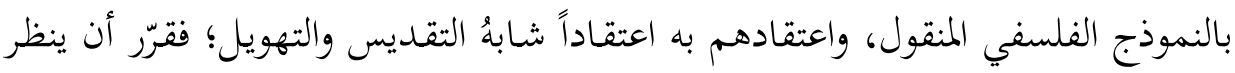

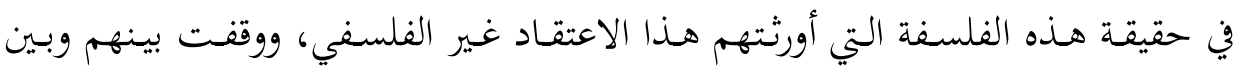

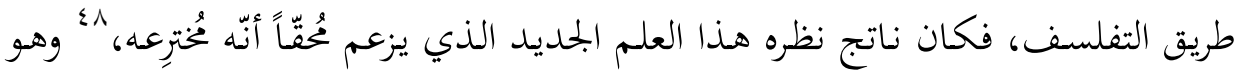

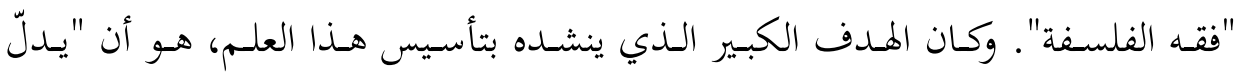

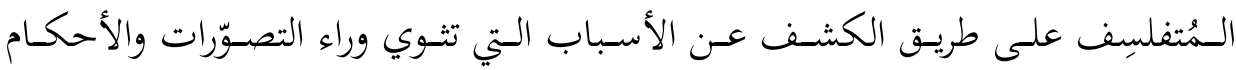

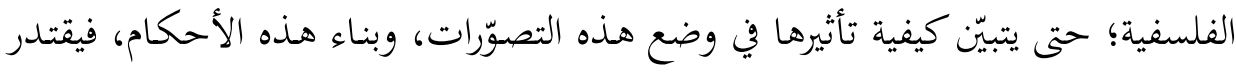

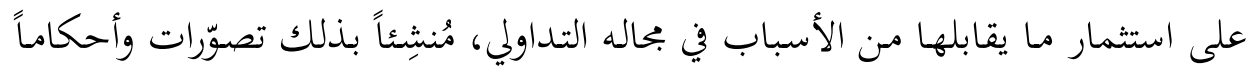

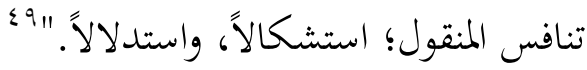

وقد كانت نُطّة طه عبد الرحمن في إماطة هـا العائق، التأمّل العميق في الظواهر

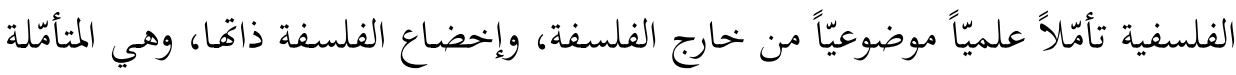

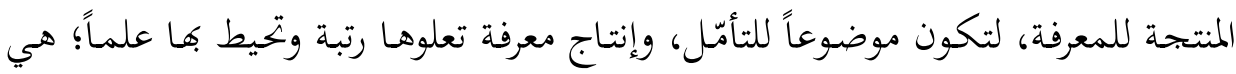

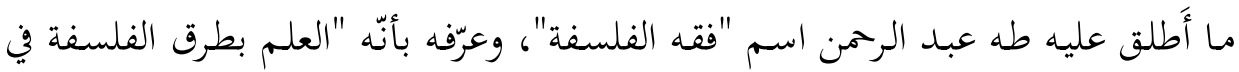

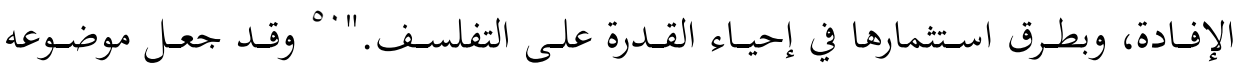

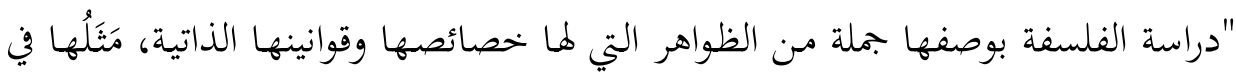

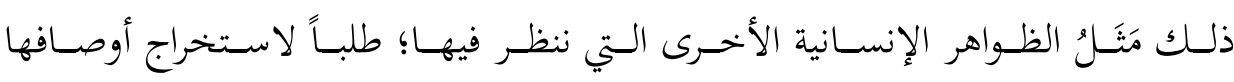

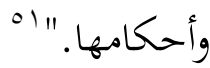

وإذ جعل طه عبد الرممن الفلسفة موضوعاً للتشريح الموضوعي والدراسة العلمية،

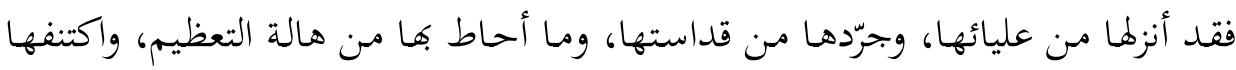

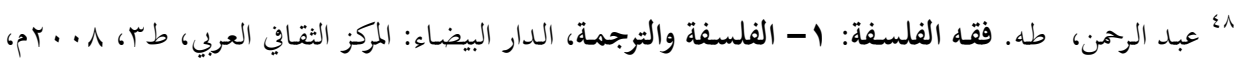

$$
\begin{aligned}
& \text { صبro }
\end{aligned}
$$

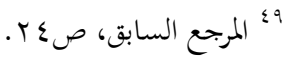

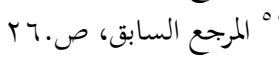

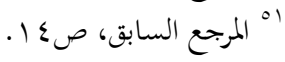




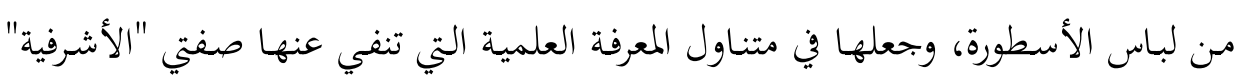

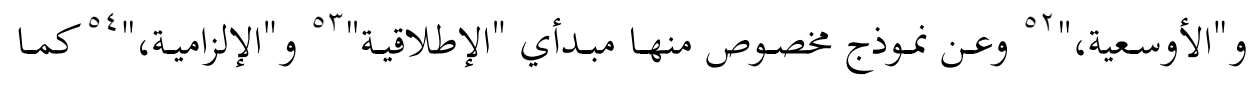

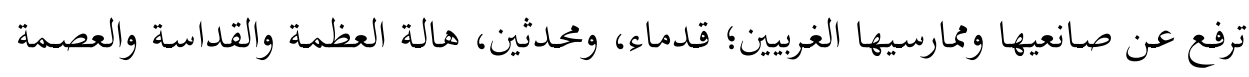

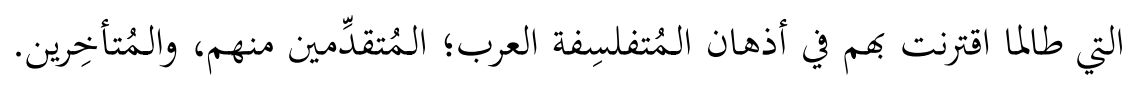

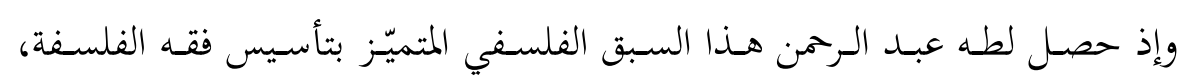

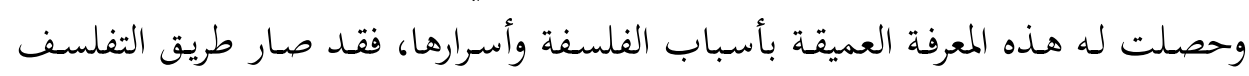

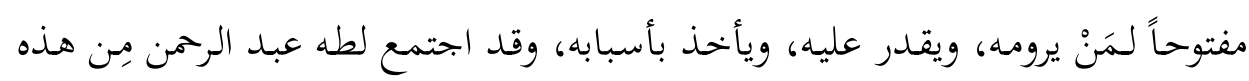

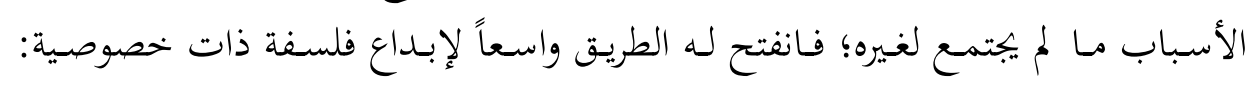
إسلامية عربية، عقلانية حوارية، أخلاقية عملية.

\section{r. إبداع فلسفة ذات خصوصية:}

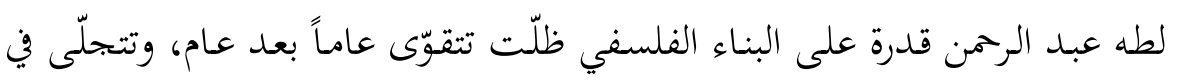

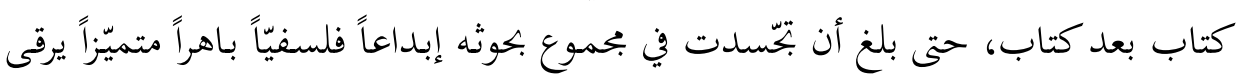

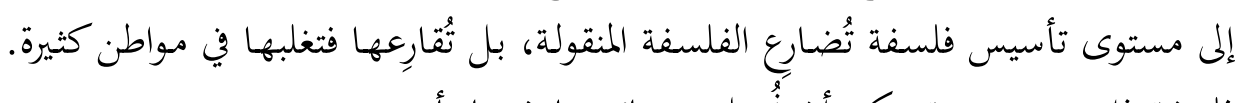

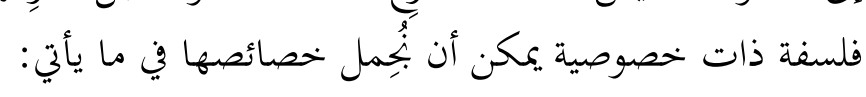

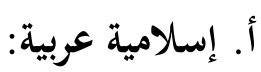

بنى طه عبد الرممن مشروع الفلسفة العربية الإسلامية على مبدأ الحقّ في الاختلاف.

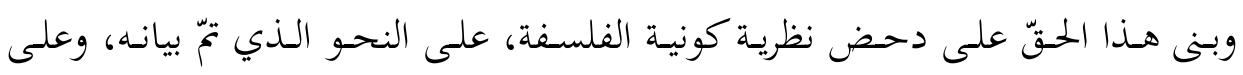

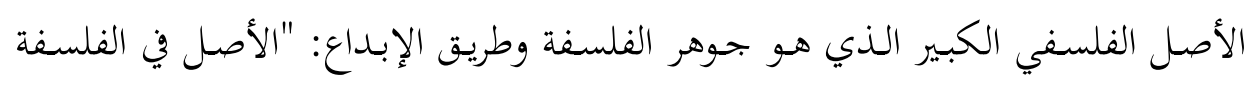

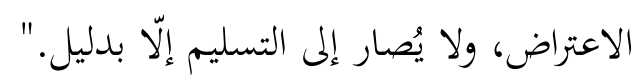

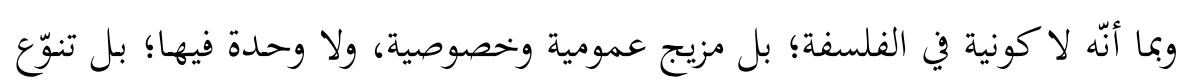

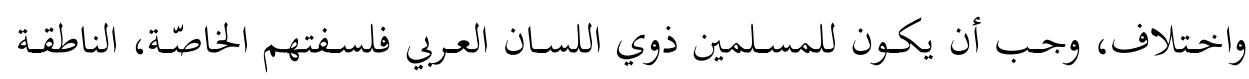

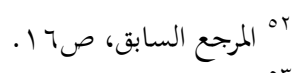

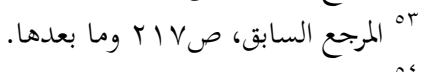

$$
\begin{aligned}
& \text { \& المرجع السابق، صع ب و وما بعدها. }
\end{aligned}
$$




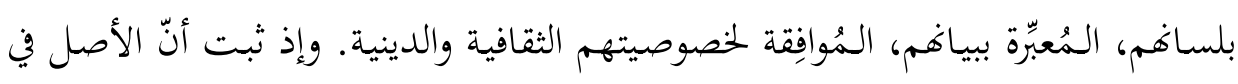

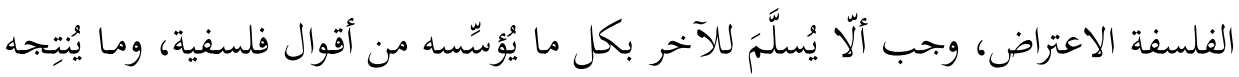

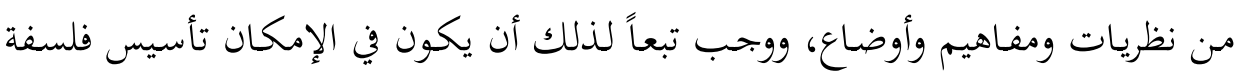
إسلامية مختلفة في أصولها ومبادئها، وفي مفاهيمها واصطلاحاتها.

تتأسّس إسلامية هذه الفلسفة على صدورها عن فيلسوف مسلم عن معرفة ويقين،

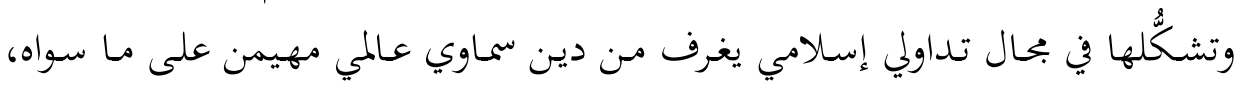

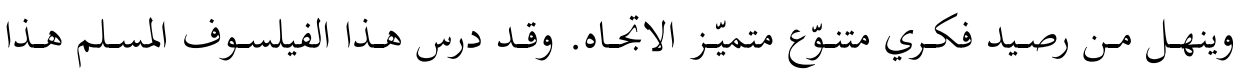

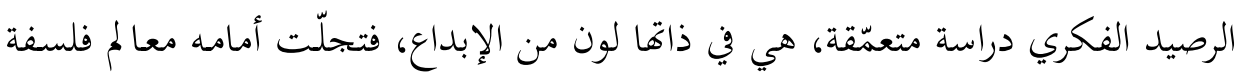

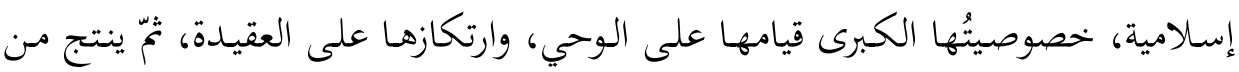

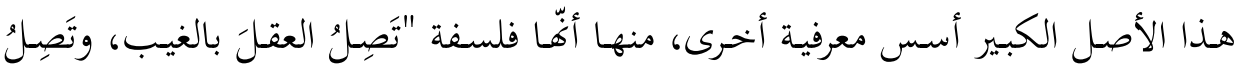

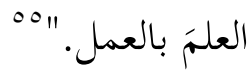

وقد كانت هذه الدراسة فرصة لتوثيق الصلة بممارسة التفلسف بمنهجية علمية وروح

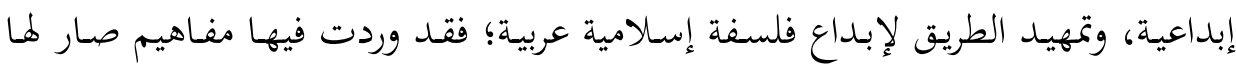

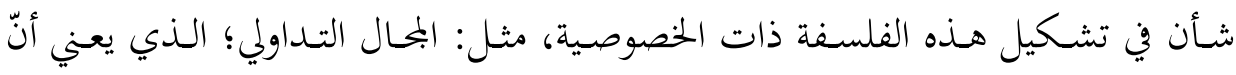

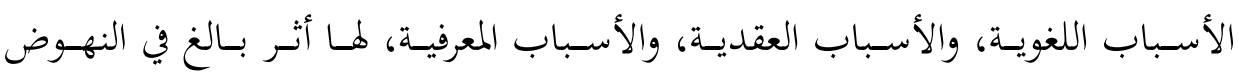

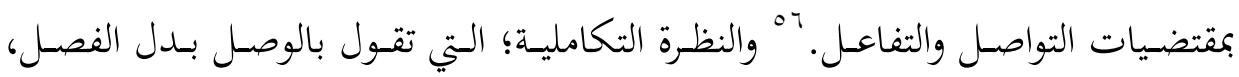

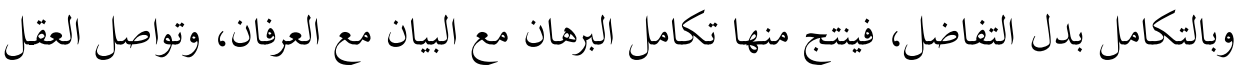

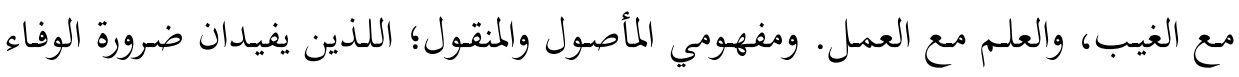

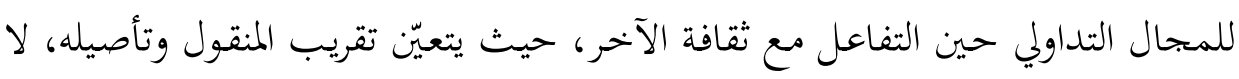
تقديمه وتقليده.

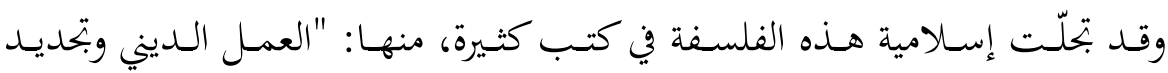

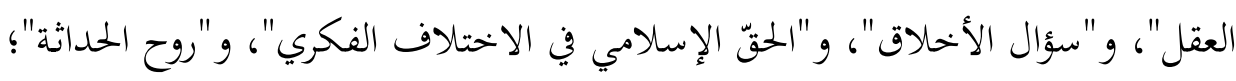

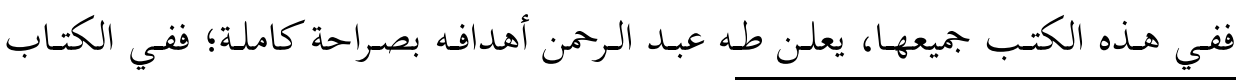

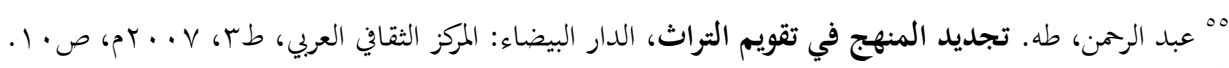

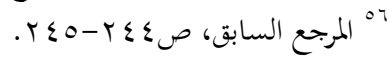




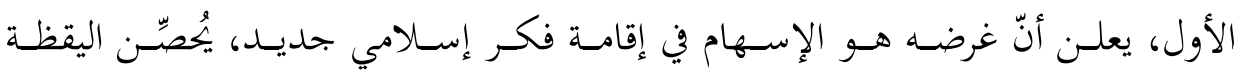

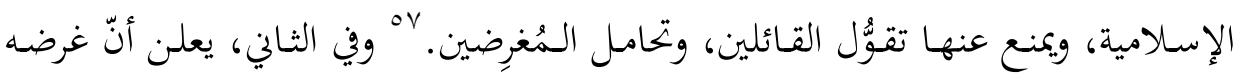

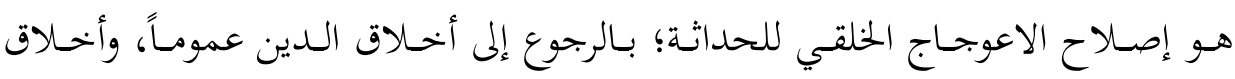

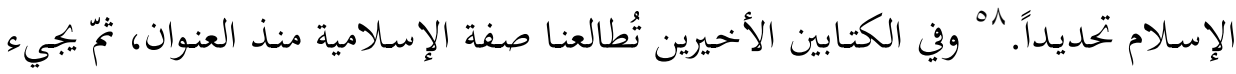
في المدخل العامّ هذا الإعلان الصريح:

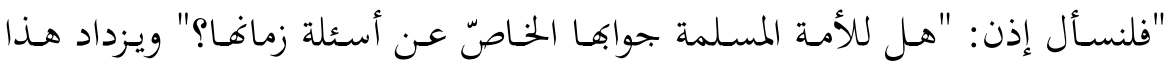

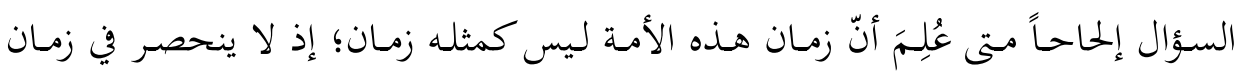

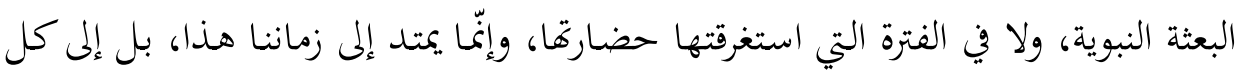

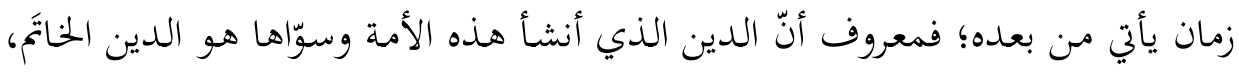

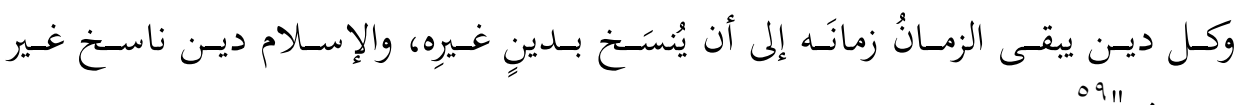
منسوخ.

"كمـا أنّ هنـاك حداثــة غـير إسـالامية، فكــلك ينبغـي أن تكـون هنـاك حداثــة

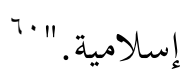

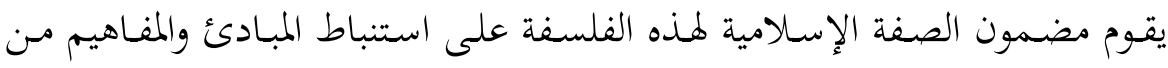

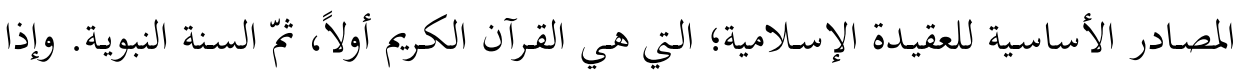

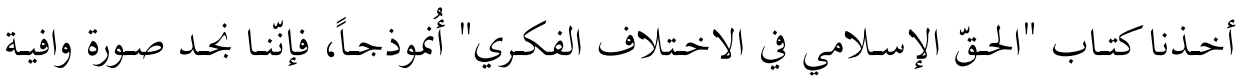

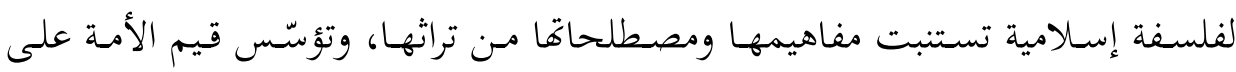

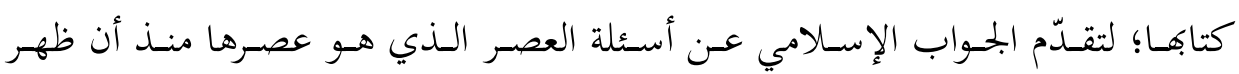

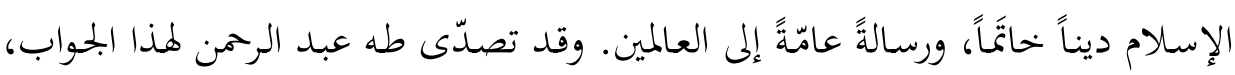

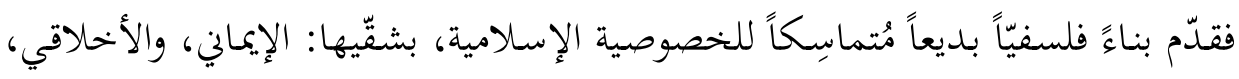
وقد شقق كل هذا البناء الفلسفي من مبدأين اثنين:

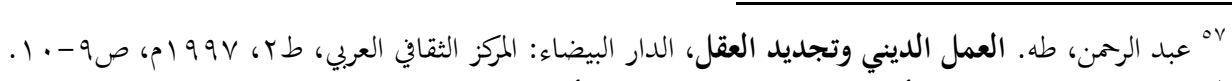

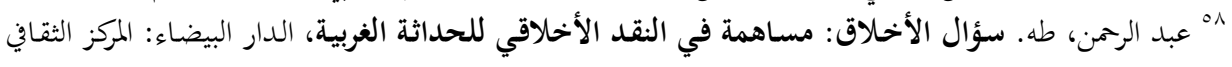

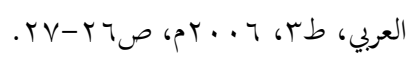

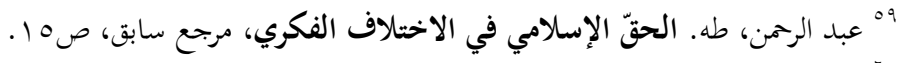

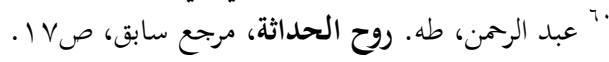


أولما مبدأ اختلاف الآيات، وينتج منه التفريق بين "الظاهرة" و "الآية"؛ إذ "الظاهرة

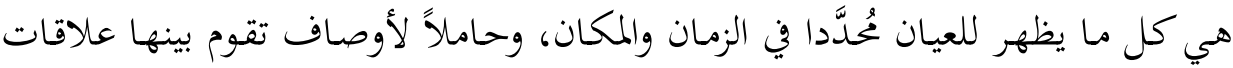

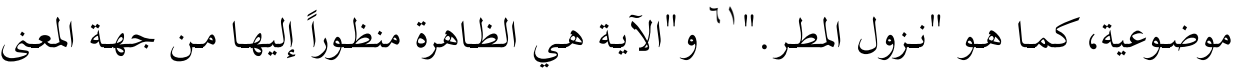

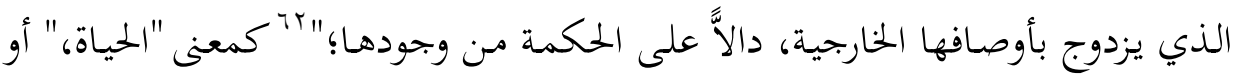

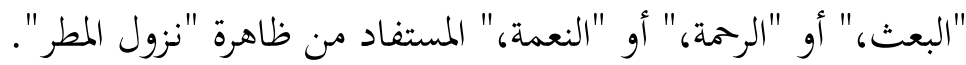

ينتج من هذا التفريق التمييزُ بين نظرين فلسفيين، يقتصر الغرب على واحد منهما،

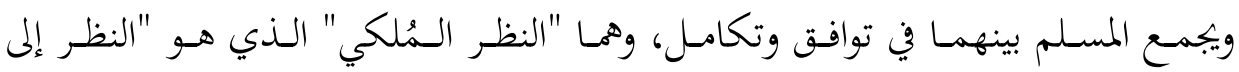

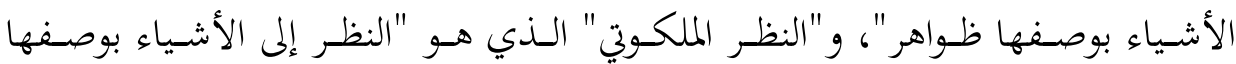

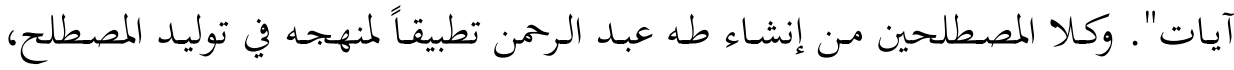

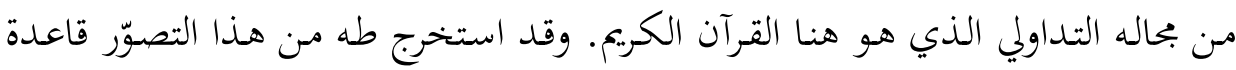

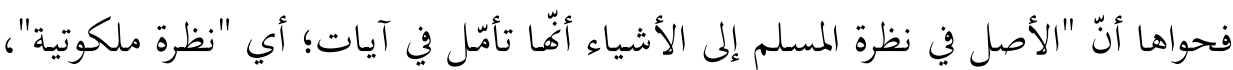

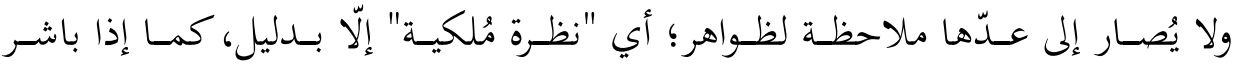

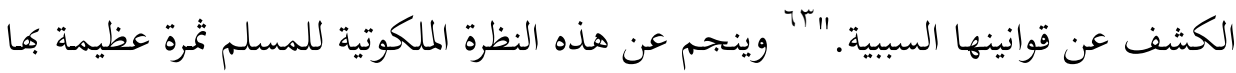

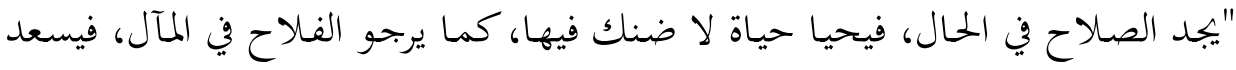

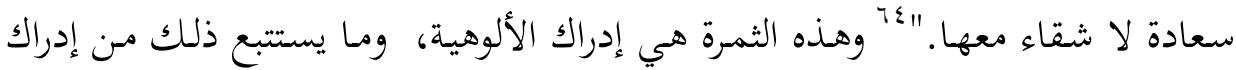
للحق والخير والجمال، ومن إدراك للسعادة تِبْعاً لذلك.

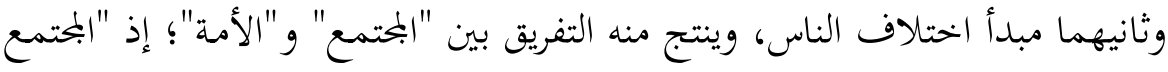

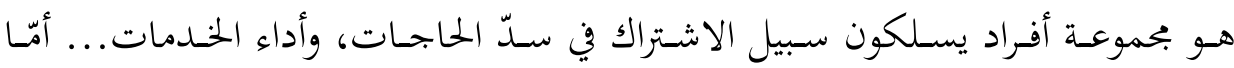

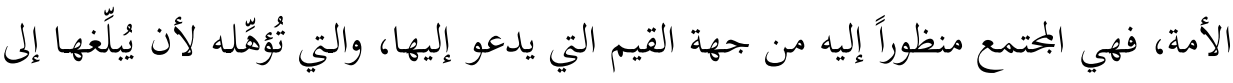

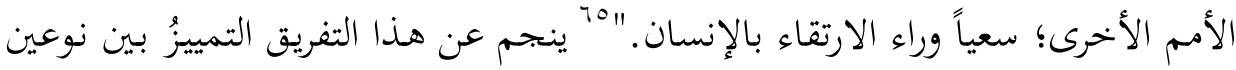

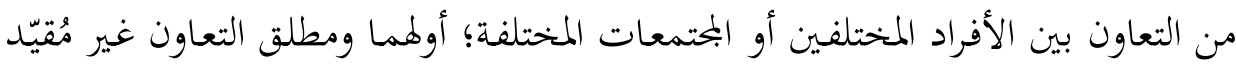

"ا" عبد الرممن، طه. الحقّ الإسلامي في الاختلاف الفكري، مرجع سابق، صیا ا.

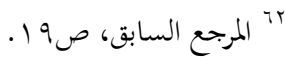

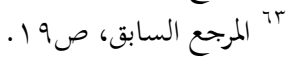

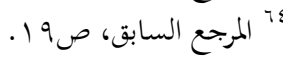

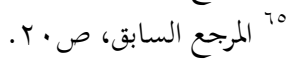


بصـفة، ويسـمّيه طـه عبـــ الرحمن "العمـل التعـاوي"ي"، والثـاني "التعامـل بــن الأشـخاص المختلفين والأمم المختلفة على مقتضى قيم الخخير"، ويسمّيه "العمل التعارفي؛" "إذ حقيقة

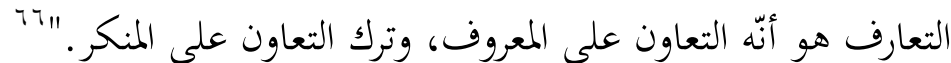

بنـاءً على هـذا التمييز يترشّح المسـلم، على الخصـوص، ليكـون "الإنسـان الذَي لا

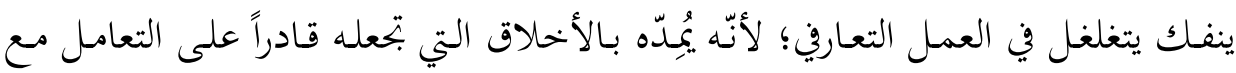

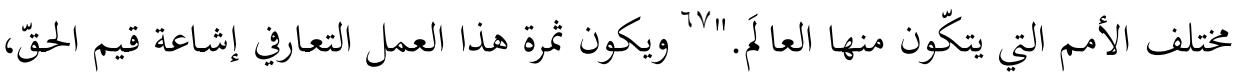

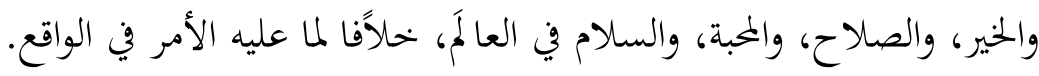

بـذا، تتميّزز روح الجـواب الإسـلامي مـن أسـئلة هـذا الزمـان؛ بحقيقتـين اثنتـين، همـا:

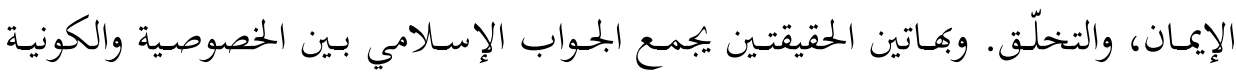
أكمل جمع وأرقاه؛ لأنّ خصوصيته "تتحلّدد باختلافية؛ إيمانيتُها أنثل إيمانية، وأخحلاقيتُها

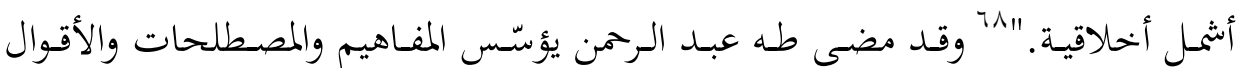

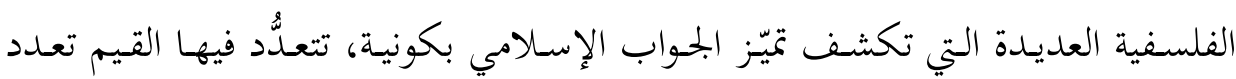
تصادف لا تصادم؛ إذ تدفع الآفات المسبّبة للتصادم، وهي "آفة تسيُّب العقل"، و "آفة

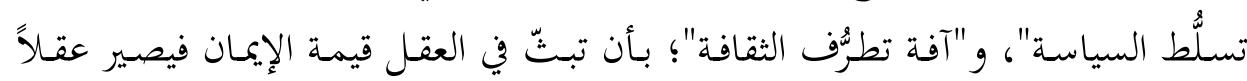

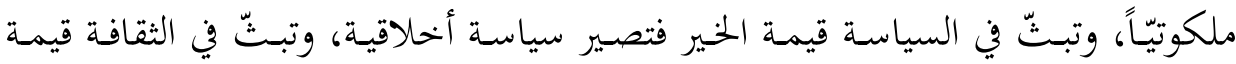
الفطـرة فتصـير ثقافـة متصـلة. وتكـون تعدّديـة الجــواب الإسـلامي، وهـي تعدّديـة القـيم المتصادفة، بديلاً عن ثقافة الواقع الكوني التي تقوم على صدم الثقافات الأخرى لإقصائها

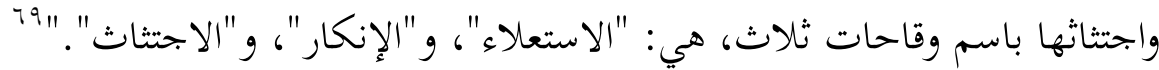
أمّـا الصـفة العربيـة لهـذه الفلسـفة، فقـــ بحسّــت في جميـع كتـبـ طـه عبــ الرحمن الفلسفية لغةً عربيةً أصيلة البناء مشرقة البيان، بتري موافقة لطريقة العرب في تحرير أقوالها؛

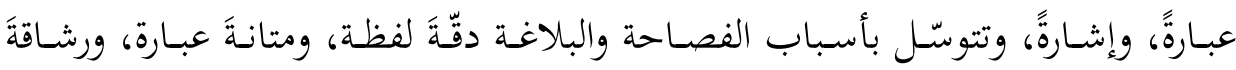

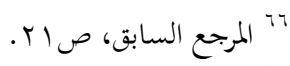

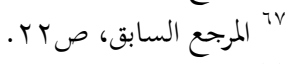

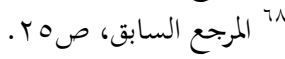

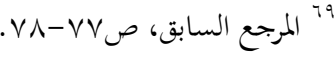




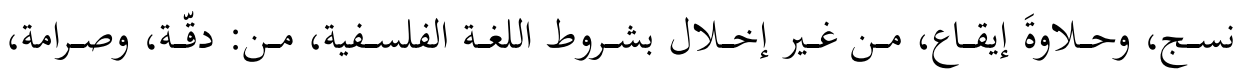

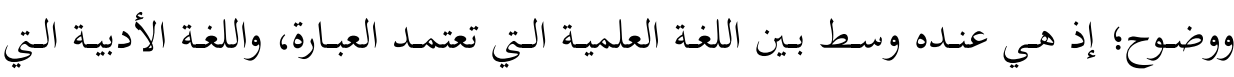

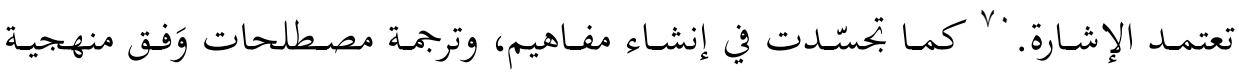

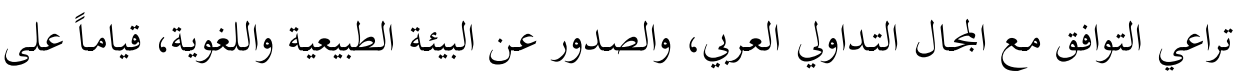

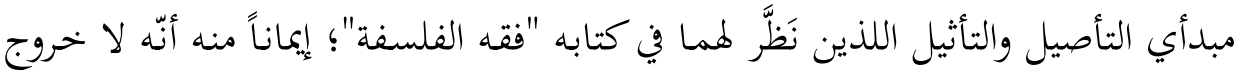

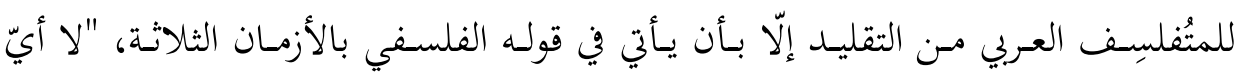

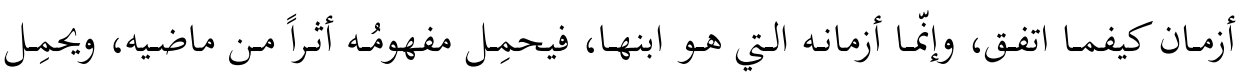

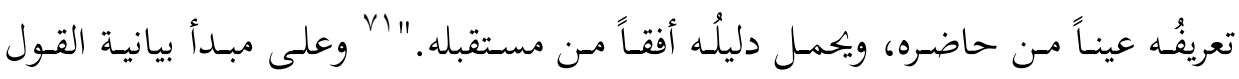

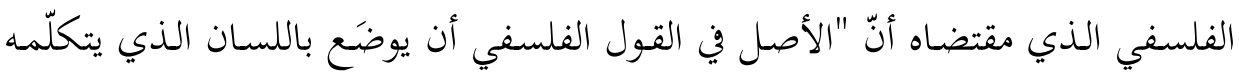

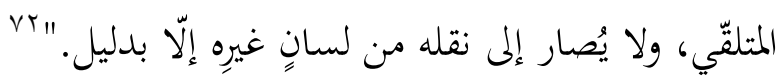

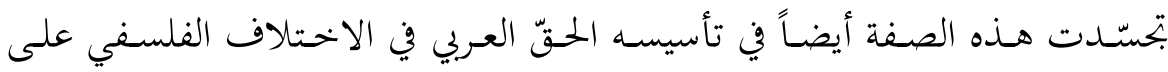

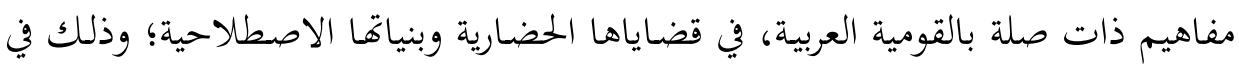
كتابه "الحقّ العربي في الاختلاف الفلسفي"؛ إذ أظهر ممارسة عملية لافتة للحقّ الطبيعي

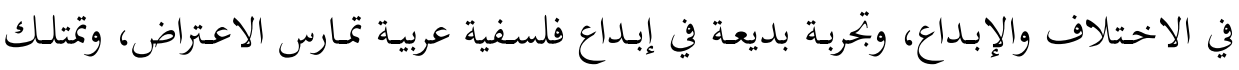

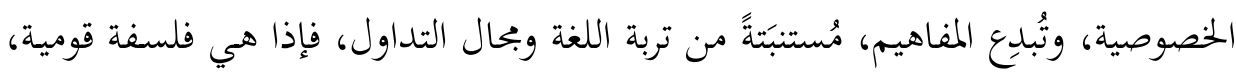

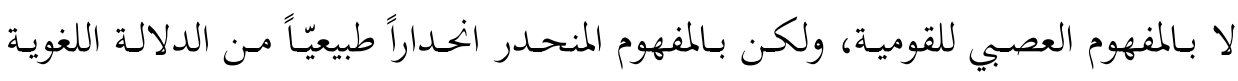

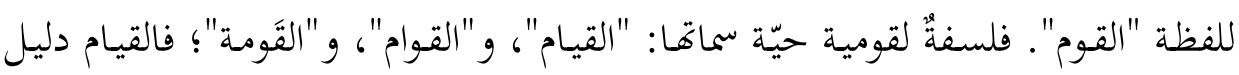

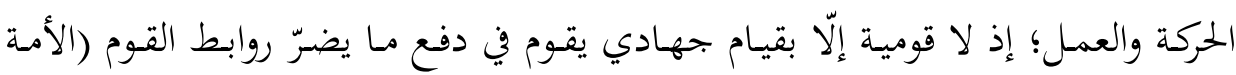

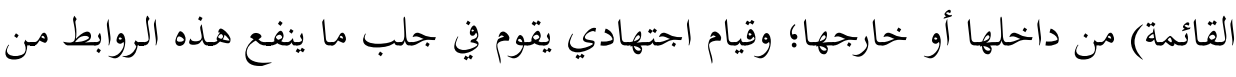

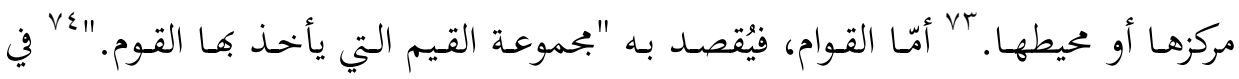

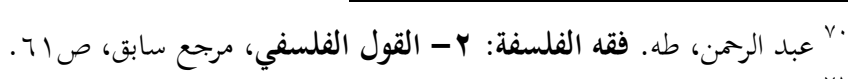

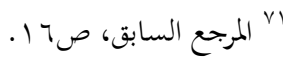

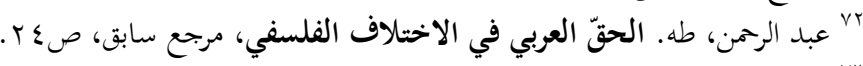

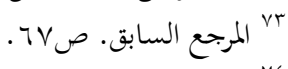

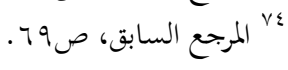




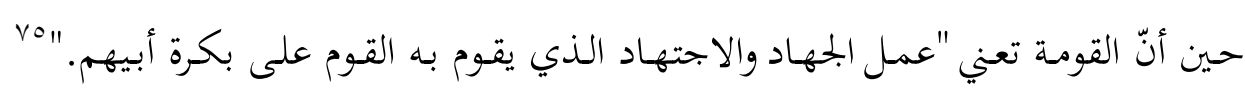
فهي أوف بمدلول مصطلح "الثورة" الذي يستعمله القوميون.

ينتج من هذه القومية الحية تحصيل قومة فلسفية تدفع عن الإنسان العربي "التقليد

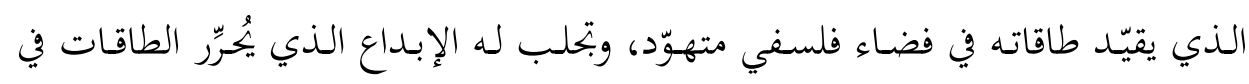

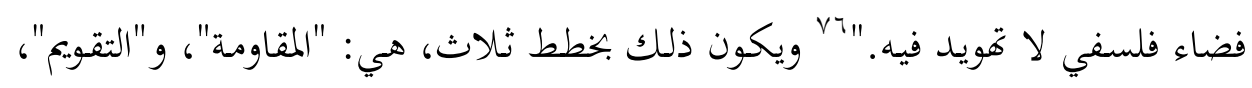

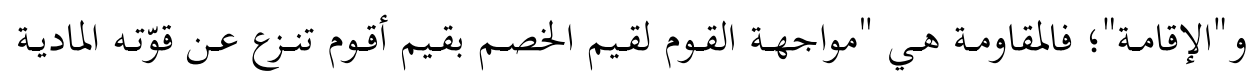

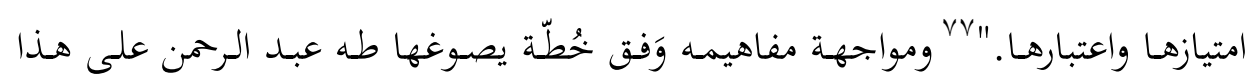

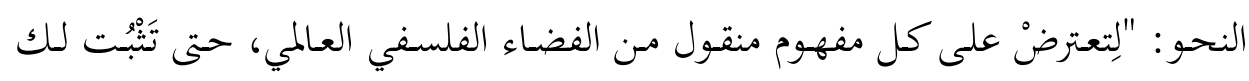

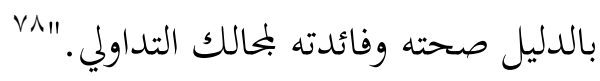

والتقويم هو "إزالة الاعوجاج"، و "التزوّد بالقيم" بما يضمن الانتفاع بالمفاهيم الفلسفية

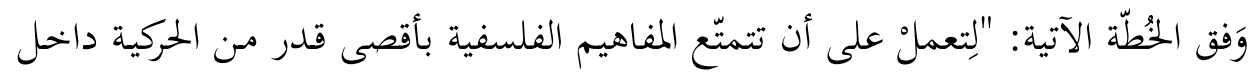

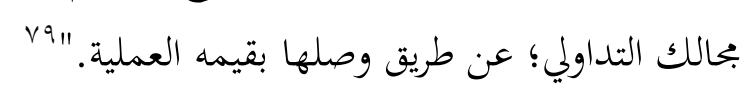

والإقامـة هي "أن نرفع المعاني المتداولـة في بجالنـا العـربي المشـترك إلى رتبـة المفـاهيم

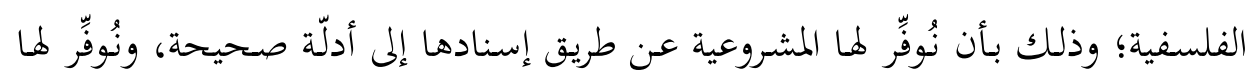

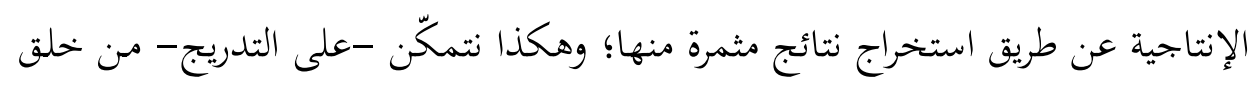

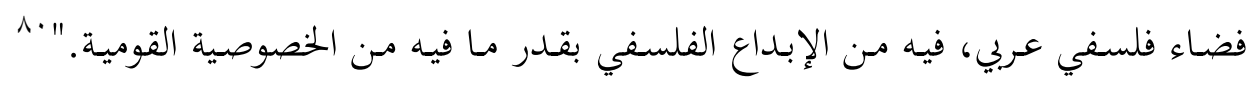

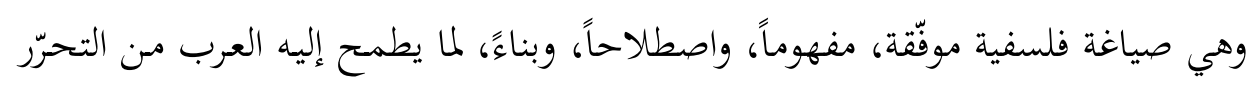
المبدع، والمثاقفة الواعية، والمقاومة الناجعة.

$$
\begin{aligned}
& \text { • "لمرجع السابق، ص. v. }
\end{aligned}
$$

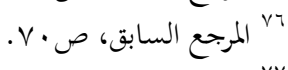

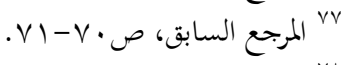

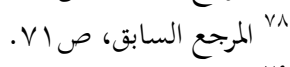

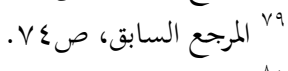

$$
\begin{aligned}
& \text { • المرجع السابق، صالق، صعا. }
\end{aligned}
$$




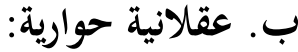

تتصـف الفلسـفة التي أبـدعها طـه عبـد الرحمن بالعقلانيـة والحواريـة، بعـد اتصـافها بالإسـالامية والعربيـة. واجتمــاع العقلانيـة إلى الإسـلامية دعـوى طالمـا اعـترض عليهـا المُتفلسِفة العرب العلمانيون، الذين يعتقدون قيام العلاقة بين الشرع والعقل، وبين الدين والعلهم، على التنـاقض والصـراع. لـذلك، تصدّى طه عبد الرحمن لـذا الاعتراض الباطل الذي لا يُسنده الدليل. ويمكن أن بُجمِل منهجيته في إثبات عقلانية الفلسفة الإسلامية

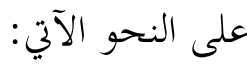

- التسـليم بعقلانيـة الفلسـفة؛ فالفلسـفة تتوسّل بالعقـل في تحصيل المعرفـة، بحيـث يكون التدليل هو الفعل العقلي الدالّ على حصول العقلانية. ويكون "الشيء العقلاني هو ما جرى فيه استعمال الأدلّة، وكان ثمرة هذا الاستعمال. "1

- نفي الجوهرية عن مفهوم "العقل "؛ فالعقل ليس ذاتاً، أو شيئاً، أو جوهراً، تُعزى إليه وظيفة الإدراك للأسباب، كمـا هـو الاعتقـاد في الفلسفة المنقولة؛ وإنّما هو فعل مـن الأفعال، أو سـلوك مـن السـلوكات التي يطلع بهـا الإنسـان على الأشياء في نفسـه، وفي أُُْقِهِ. هو فعل معلول لذات حقيقية، هي ميزة الإنسان في الممارسـة الفكرية الإسـلامية العربية، ألا وهي "القلب" هوده استناداً إلى نسبة فعل العقل إلى القلب في القرآن الكريم.

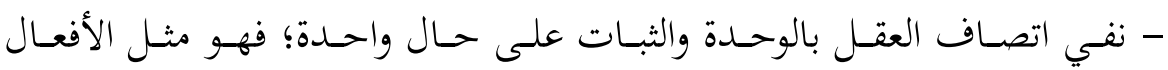
والصفات، قد يحسُن، وقد يقبح، وهو لتبعيته للقلب "يمكن توجيهه والتأثير فيه، بحيث

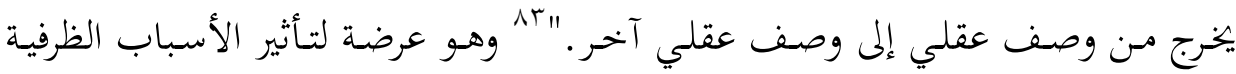
والملابسات العرضية، بحيـث يمكـن القول إنّ المنهج العقلي المسلوك في الفلسفة المنقولة

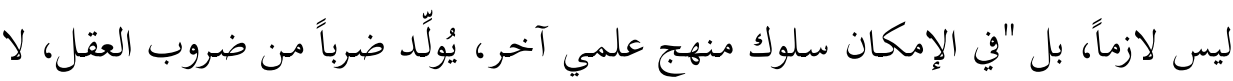

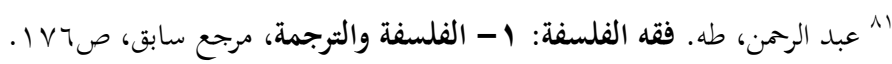

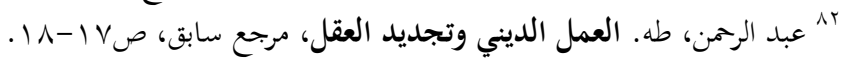

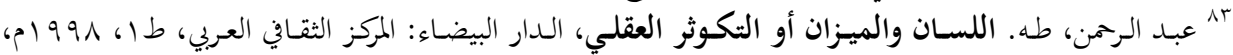




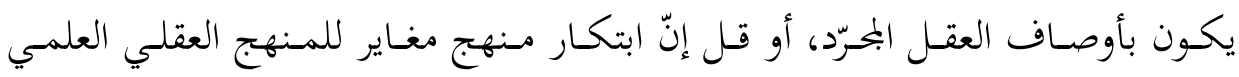
المتداول في العلوم النظرية السـائدة حاليّاً، منهجٍٍ لا يقل عقلانية وعلمية عن مـنهج هذه العلوم، هو حقيقة يجب التسليم بها."

- التشكيك في يقينية البرهان العقلي، مُ والقول بمحدودية العقل المجرّد، وحاجته إلى

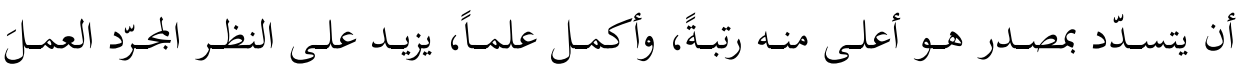
المشتصف، بما يوسّع آفاقه ويعمّقها. وليس هذا الذي يوحّد بين النظر والعمل بمـا يعود بالنفع الأكيد سوى الشرع الإلهي الأسمى.

- القول بتقييد العقل تناسباً مع دلالته اللغوية؛ وهي القيد. وما يوجب ذلك "أنّ

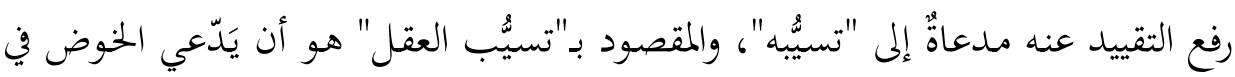

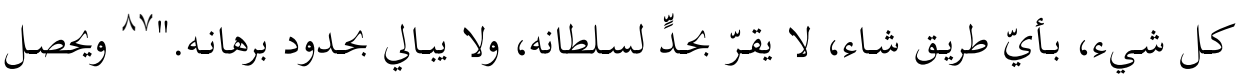

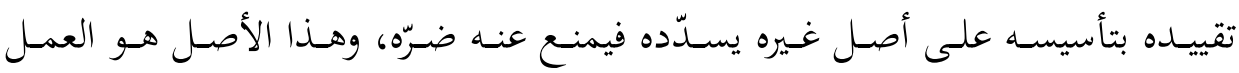
الأخلاقي، أو العقيـدة الدينيـة. وقـد عملـت الفلسفة المنقولة بعكس ذلك؛ إذ حاولت تأسيس هذين على مبادئ العقل البحرد.

وبناءً على هذا التصوّر لعلاقة العقل بالدين، وبالعقيدة الإسلامية تحديداً، وجبب أن تكون للفلسفة الإسلامية عقلانية خاصّة بحمع بين العقل والغيب، والعلم والعمل، وتقول بتأسيس العقل على الوحي، فينتج من ذلك توسيعه، وتسديده، وتأييده. وقد اعترض طه

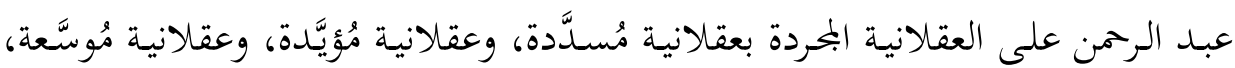
وعقلانيـة أخحلاقيـة. وكـل هـــه العقلانيـات تقـوم علـى أصـل واحــ، هـو الشـرع الإلهي الأسمى، بجانبيه: الإيماني، والعملي. ويمكن أن نُضمِّن العقلانيات التي يقول بها طه عبد

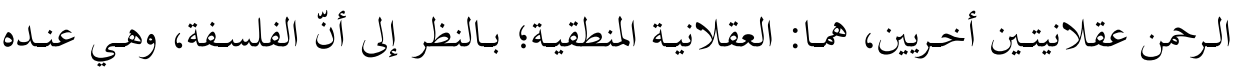

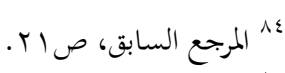

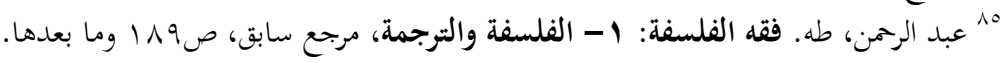

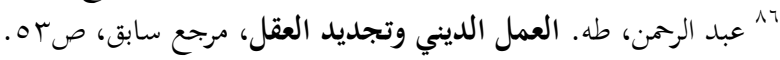

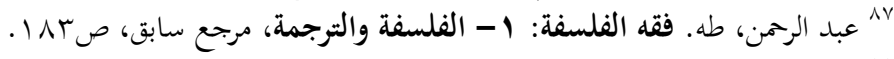

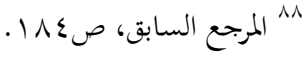




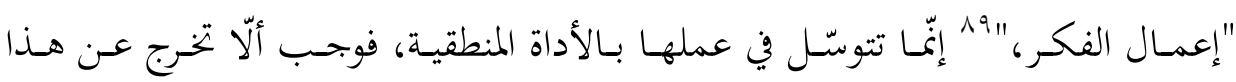

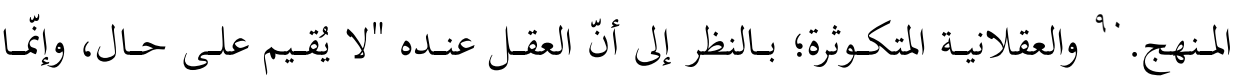

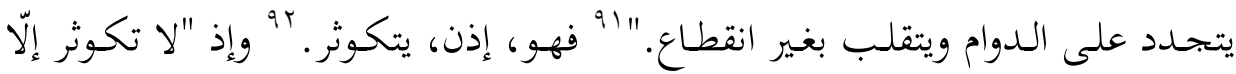

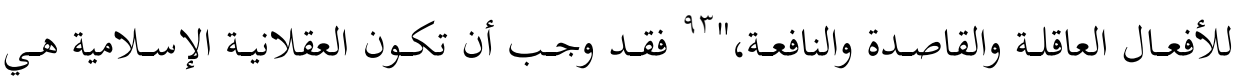
أحظى العقلانيات بخصيصة التكوثر.

وقد مـارس طه عبـد الرحمن، في جملة كتبه، هـذه الفلسفة العقلانية المتميّزة؛ ففي

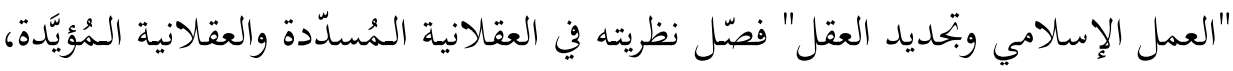

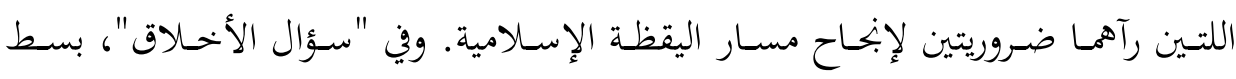

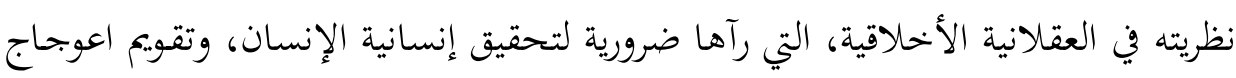

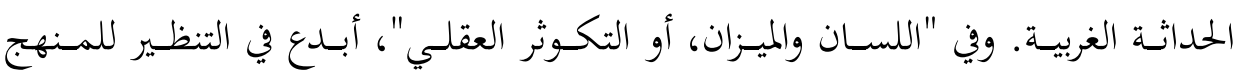

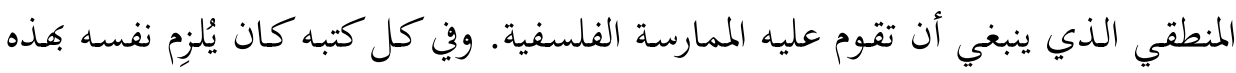

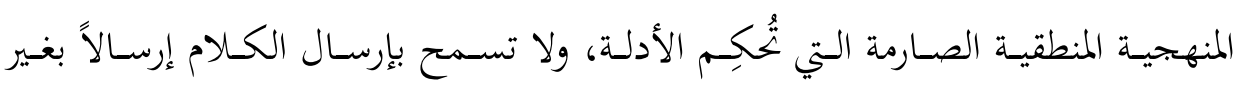

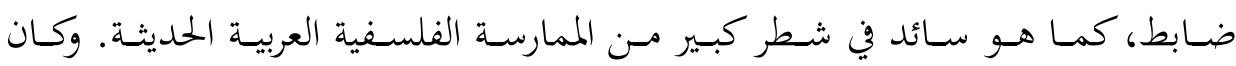

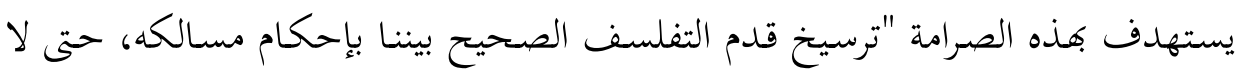

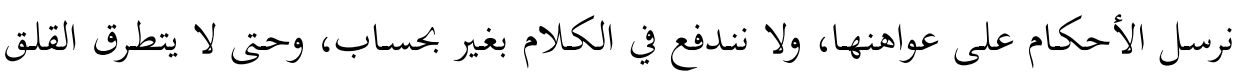

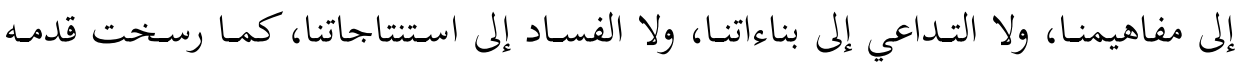

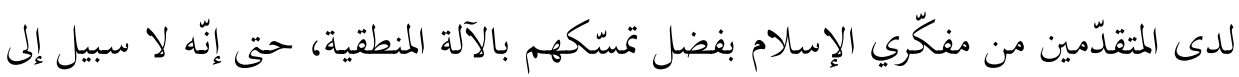

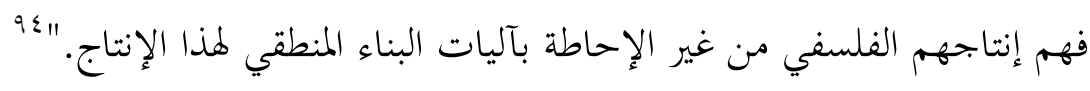

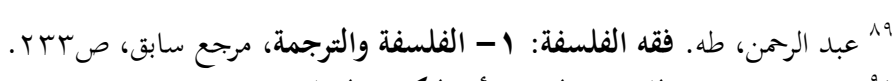

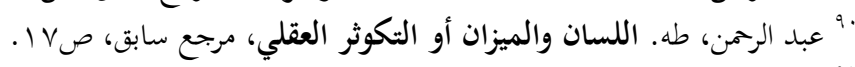

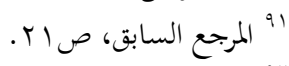
"ar التكوثر : مصطلح فلسفي من وضع طه عبد الرمن، يقصد به تكاثراً خخصوصاً، هو التكاثر الذي يخصل في عمل العقل بتوجه قصدي إلى النفع.

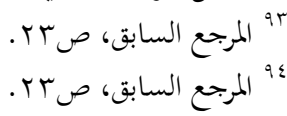


أمّا الحواريـة، فهي خصيصـة منهجيـة خطابيـة اختارهـا طـه عبــ الرحمن لمصـاحبة عقلانيته الإسلامية. وهي ذات صلة بالمحال التداولي الإسلامي العربي؛ إذيحفل الخطاب القرآي بالحوار وسيلةَ إبلاغ وحجاج، وحيث "يقوم اللسان العربي على قانون عامّ، هو

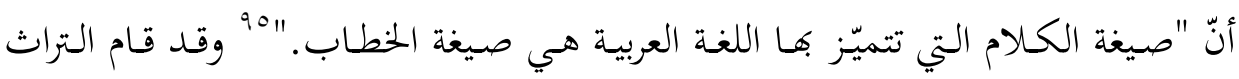

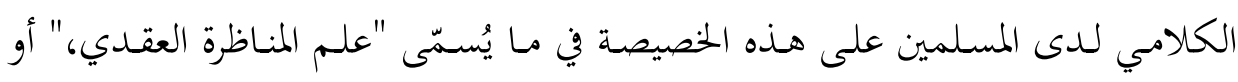

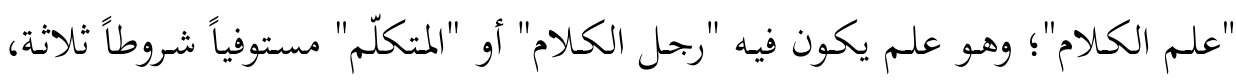
هي: الاعتقاد، والنظر، والمحاورة. 97

وقـد نظّر طه عبـد الرحمن لهذه الحوارية في كتابين مهمـين، هـا: "اللسـان والميزان"، و"الحقّ العربي في الاختلاف الفلسفي". ويمكن أن نُجمِل حصيلة هذا التنظير في ما يأيت : - الخطاب هـو الأصل في كل تعاملـ، وماهيـة الخطاب تكمسن في أنّه يضسف إلى قصد التوجّه إلى الآخر، وقصد الإفهام قصدين معرفيين، هما: "قصد الادعاء"، و وقصد

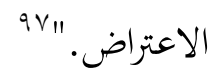

- حقيقـة الخطاب الانبنـاء على "العلاقـة الاستدلالية"؛ إذ إنّ "الـمُدّعي هـو عبـارة عن المُحاطِب الذي ينهض بواجب الاستدلال على قوله." و "المُعترِض هو عبارة عن إن

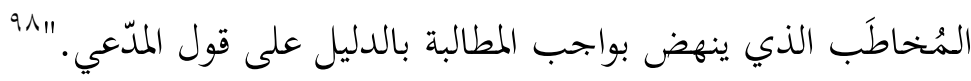

- التخاطب بنيـة تفاعليـة تقوم على مبـادئ تواصلية وتعامليـة مشروطة في تحصيل

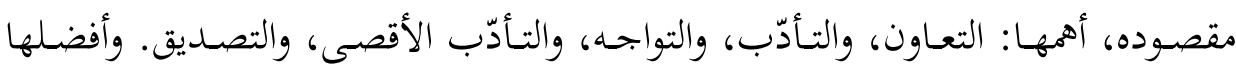

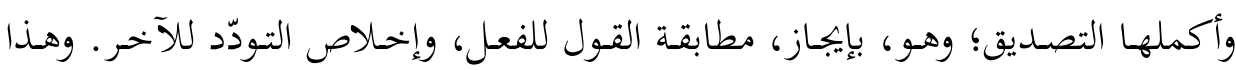

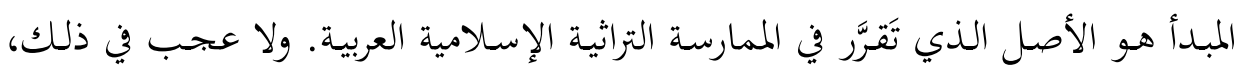
يقول طه عبد الرحمن: "إذ معاناتا للتخاطب كانت أصدق حالاً، وأفسح بحالاً، وبالتالي

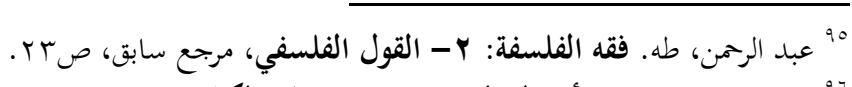

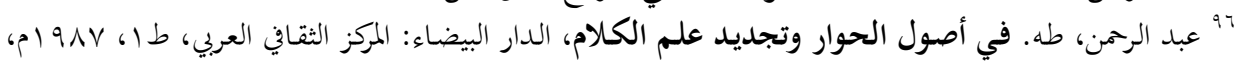

$$
\text { صلآ7 وما بعدها. }
$$

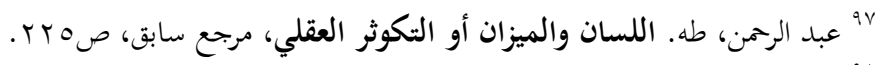

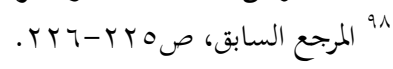


لا بُدّ أن يكون نظر أهلها في التخاطب أصحّ حكماً، وأبلغ أثراً، ألا ترى أَّمّم تركوا فينا

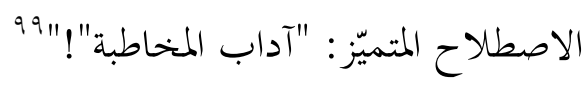

- الأصـل في الكـلام الحــوار، والأصـل في الحــوار الاخهتلاف. ”' ومـع أنّ الحــوار يقتضي الجماعـة، والاختـلاف يقتضي المنازعة، فبإن الحموار يؤول إلى الألفـة بـدل النزاع،

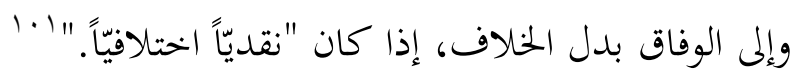

- "الحوار النقدي،" هو "الحوار الاختلافي الذي يكون الغرض منه دفع الانتقادات -أو قل الاعتراضات- التي يوردها أحد الجحانبين المتحاورين على رأي -أو قل دعوى-

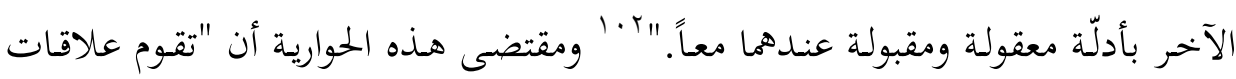
التعامل فيها، مـن جهة، على فعل الإقناع الذي يحمل تمّام الاعتبار لذات الغير، ومـن

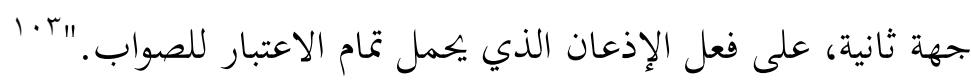
- للحوار النقدي الاختلافي ضوابط صارفة لآفة العنف، هي: ضـابط حرية الرأي وحرية النقد، وضابط الحقائق المشتركة، وضابط قواعد الاستدلال. وضوابط صارفة لآفة الخـلاف، هي: ضـابط واجـب الإثبـات، وضـابط الإثبـات الأنسـب، وضـابط الاعـتراض الأنسـب. وضـوابط صـارفة لآفـة الفرقـة، هي: ضـابط إحكـام العبـارة، وضـابط استقامة

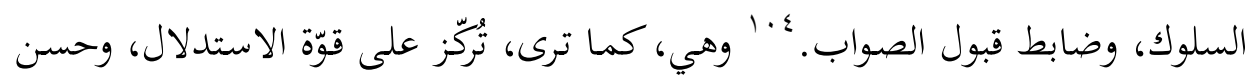

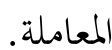

هـذه هي مبـادئ الخصصسية الحواريـة في فلسـفة طـه عبـد الرحمن. وهـو لم يكتـفِ بالتنير لها على النحو الذي أوضحنا، بل مارسها بشروطها أحسن ممارسة: استدلالاً،

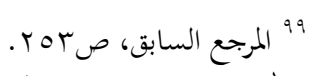

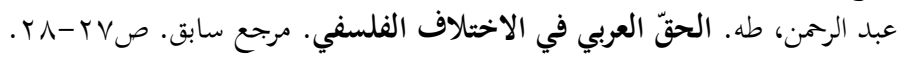

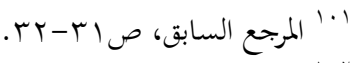

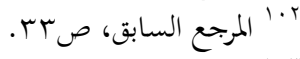

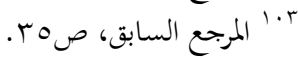

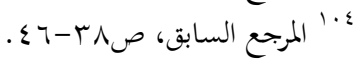


وسـلوكاً؛ فلـم يتهـاون في التـدليل علسى دعــاواه، ولم يعـدِل عـن الإحســان في محساورة المُخحالف. وساكل فلم

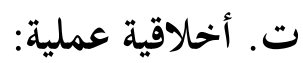

تتميّز الفلسفة التي أنشأها طه عبد الرحمن من الفلسفة المنقولة بأهّا أخلاقية عملية.

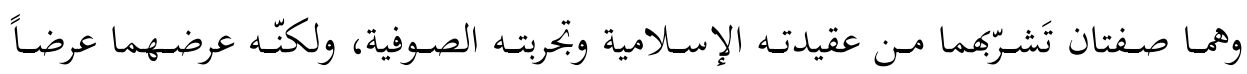

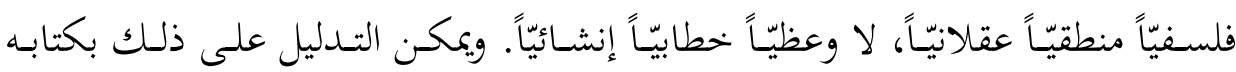

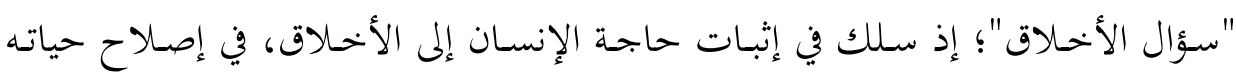

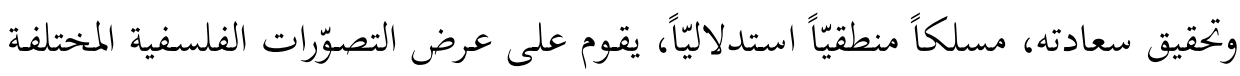

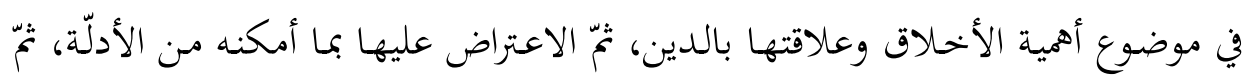

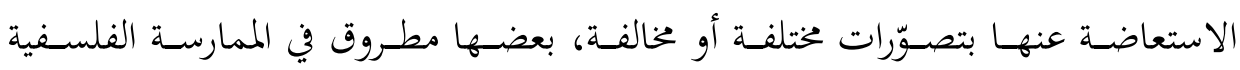

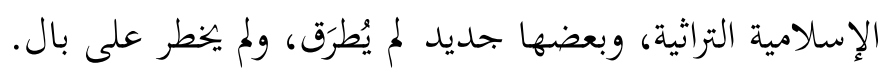

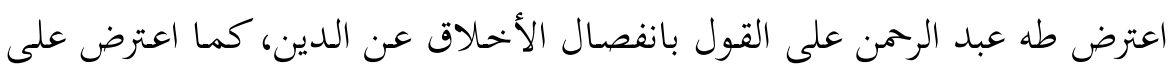

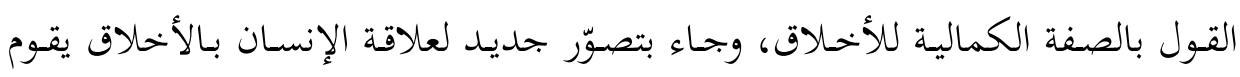

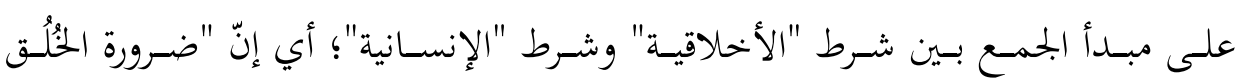

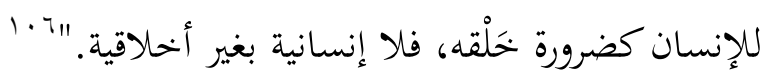

وقد اعتمد على هذا المبدأ في نقده للحداثة الغربية القائمة في بعض مفاهيمها على

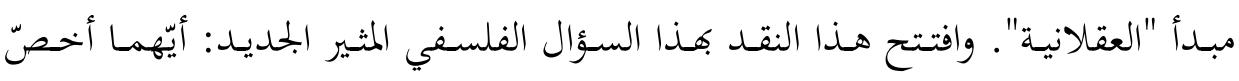
بالإنسان: العقلانية أم الأخلاقية؟ مافئح

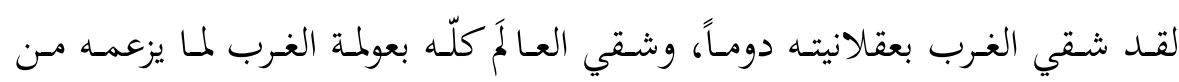

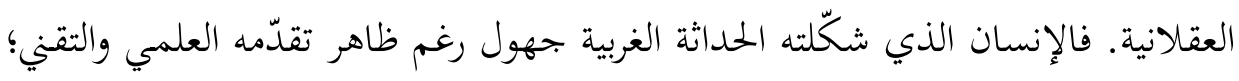

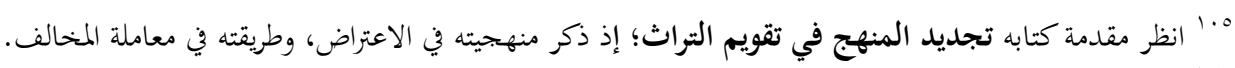

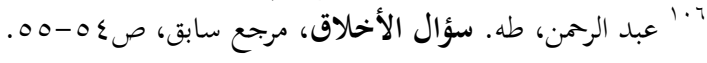




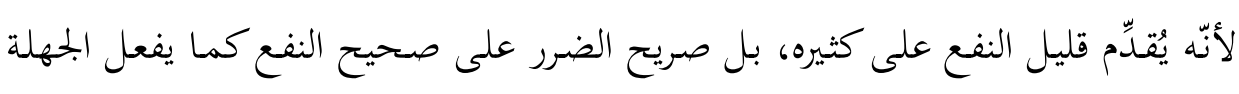

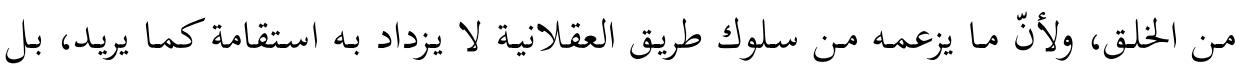

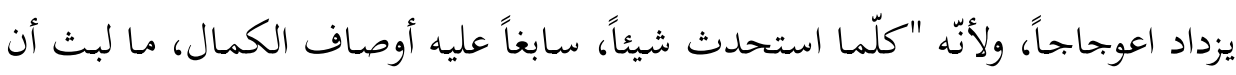

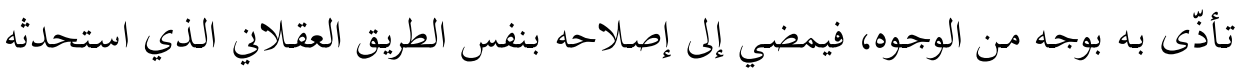

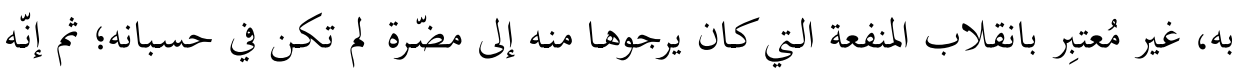

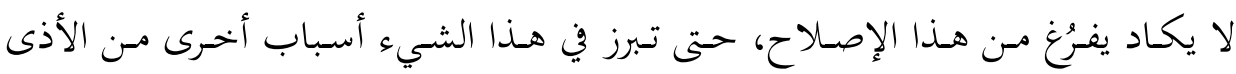

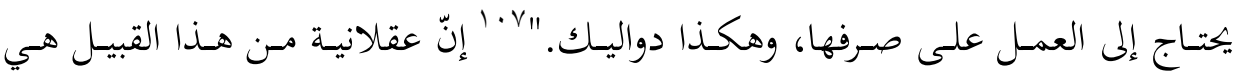

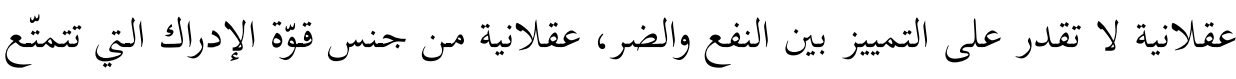
كا البهيمة؛ فهي إذن ليست بحلِّ فاصل بين الإنسانية والبهيمية.

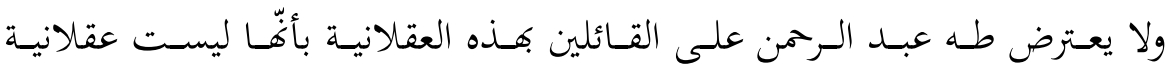

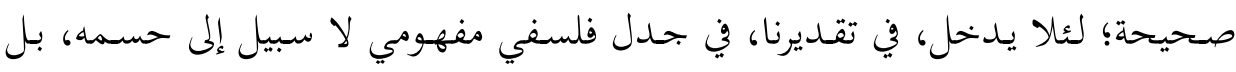

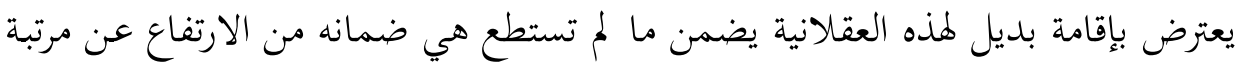

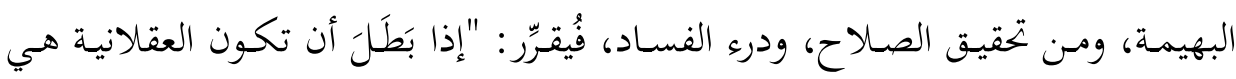

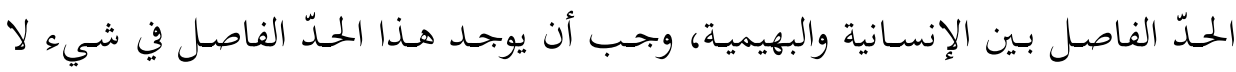

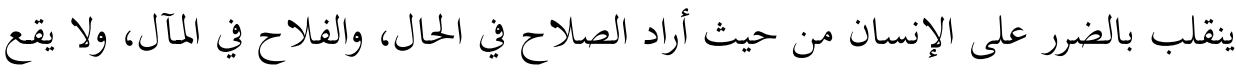

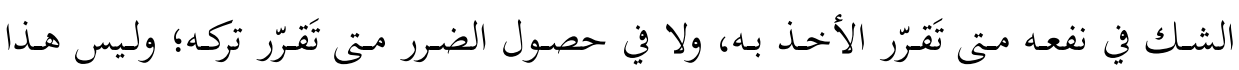

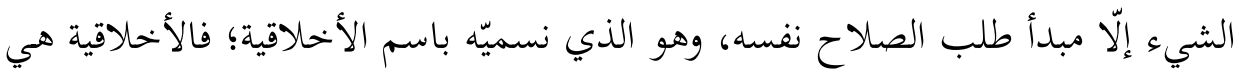

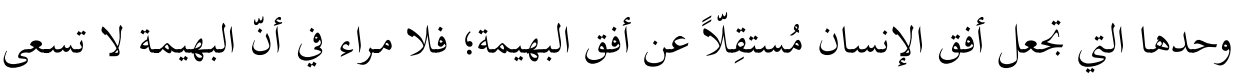

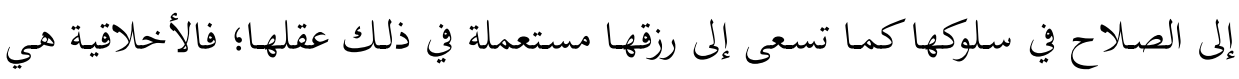

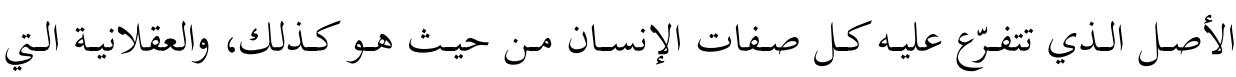

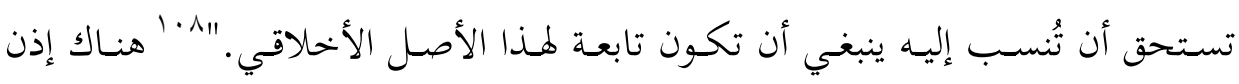

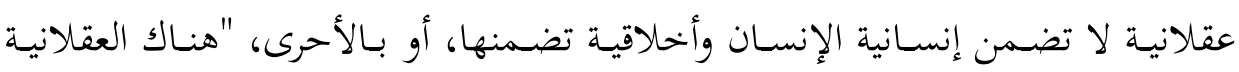

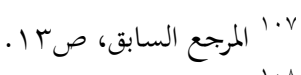

$$
\begin{aligned}
& \text { ^•1 المرجع السابق، صع ال. }
\end{aligned}
$$


البحرّدة من "الأخلاقية"، وهذه يشترك فيها الإنسان مع البهيمة، وهناك العقلانية المُسدَّدة البحة

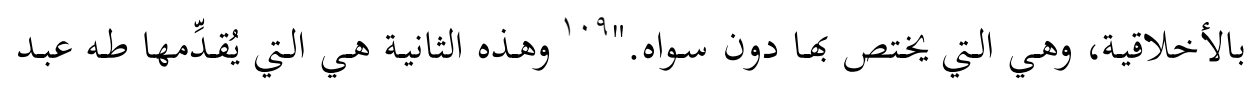
الرحمن بديلاً إسلاميّاً عن عقلانية الغرب.

والعملية صفة مصاحبة للأخلاقية؛ فالخُلق عمل، والعقلانية البحرّدة لا تبالي بخلق ولا

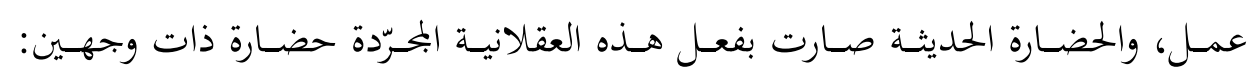

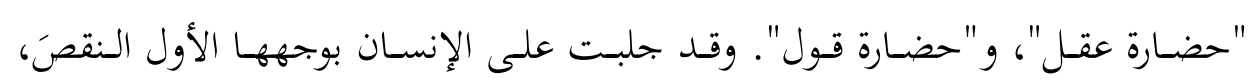

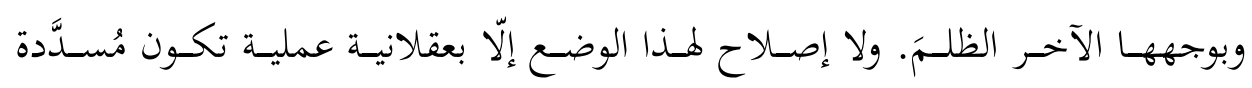

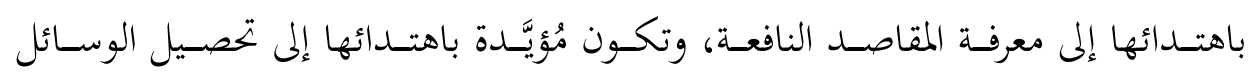

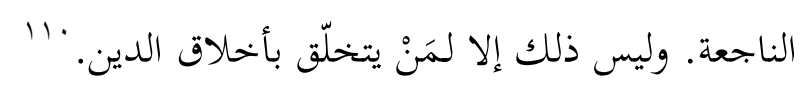
إنّ الفلسفة الغربيـة قـد غلـب عليهـا الاشتغال بـالطرق الاستـلالية على حسـاب

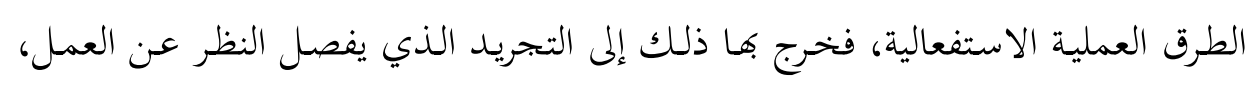

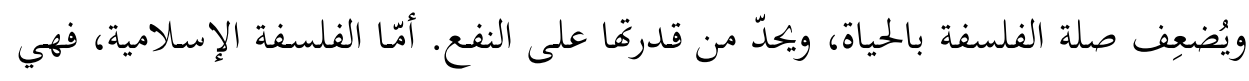

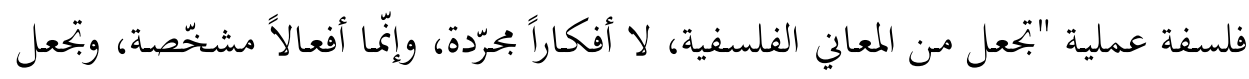

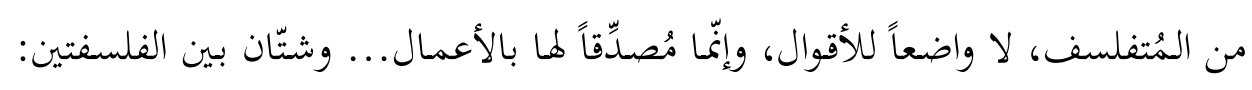

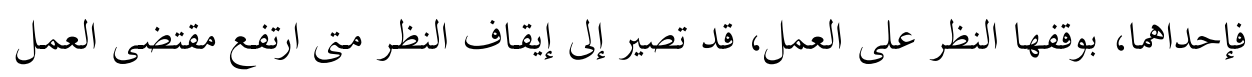

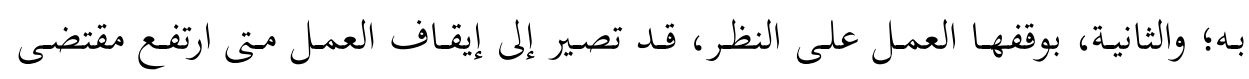

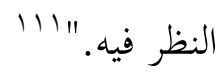

وقـد عكف طه عبـد الرحمن، في كثير مـن كتبـه، خاصّة مـا اتصل منهـا بفلسفة

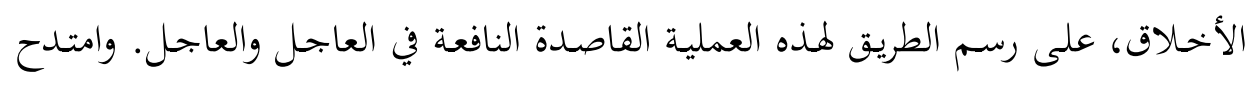

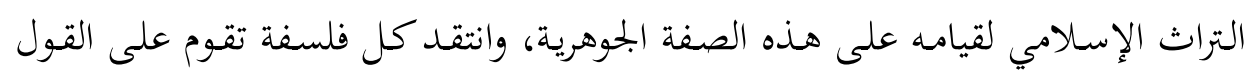

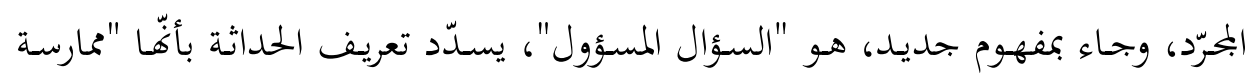

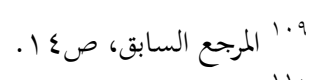

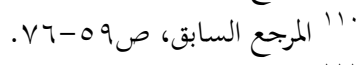

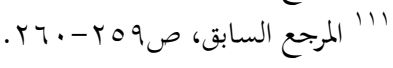




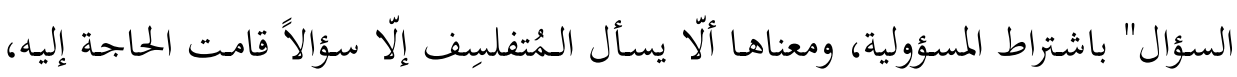

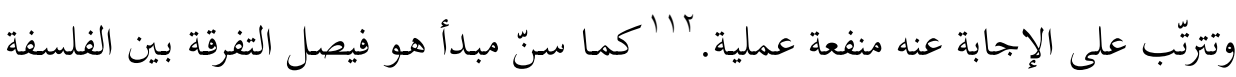

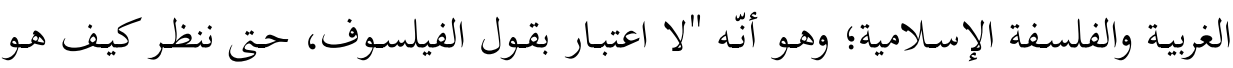

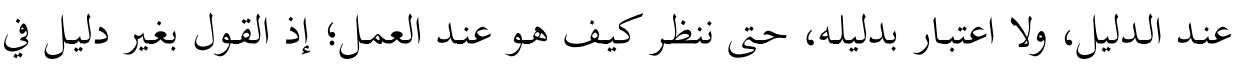

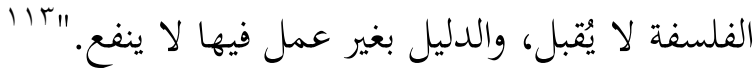
وبهذه الأخلاقية العملية تكتمل صورة الفلسفة ذات الخصوصية التي عكف طه عبد

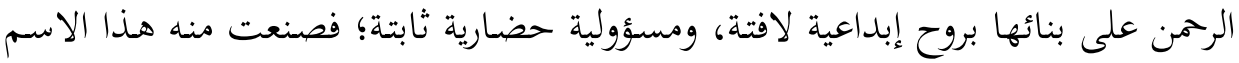

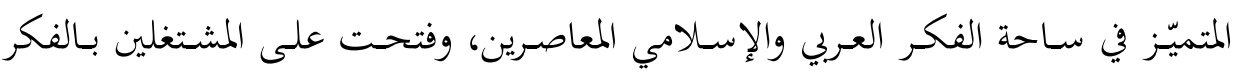

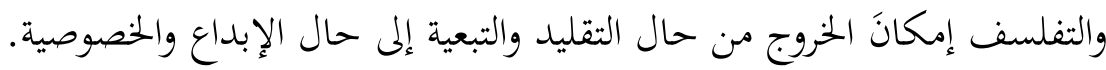

خاتمة:

تصدّينا في هذا البحث لقراءة الإنحاز الفكري لطه عبد الرحمن من زاوية نظر محدّدة؛

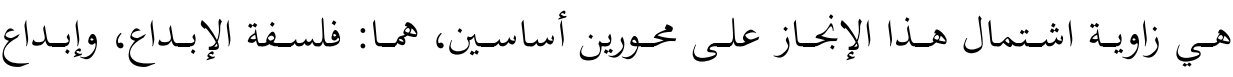

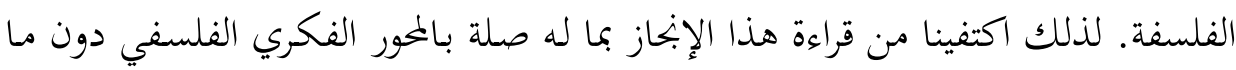

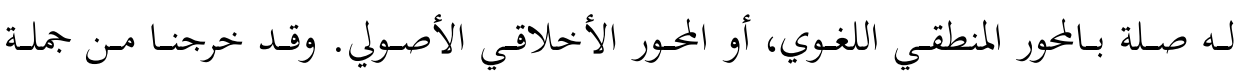
البحث بالخلاصة الآتية:

إنّ قراءة الإنحاز الفكري لطه عبد الرحمن، هي قراءة لمشكلة الإبداع في فكرنا العربي

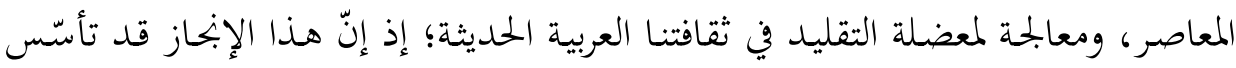

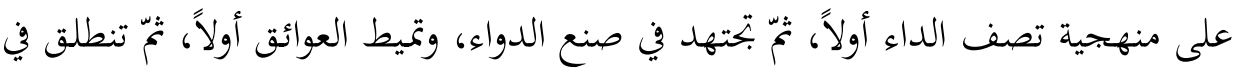

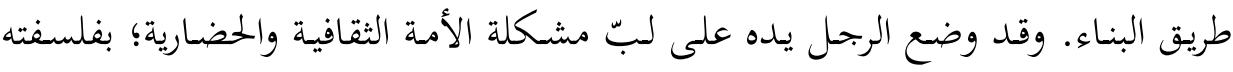

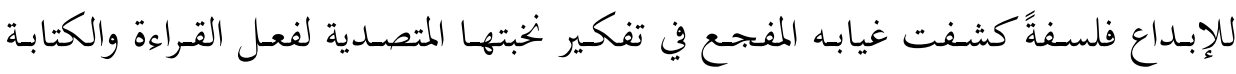

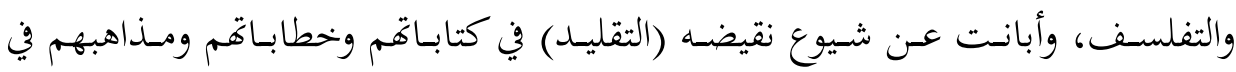

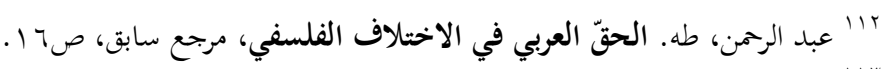
rا" المرجع السابق، ص. بـ. 
القراءة والتحليل والفكر، وعزت ذلك إلى غياب جوهره (الاعتراض)، والسقوط في موانعه من اعتقاد إعجاز القول الفلسفي، وتقديس القول الفلسفي المنقول، واعتقاد استقلال

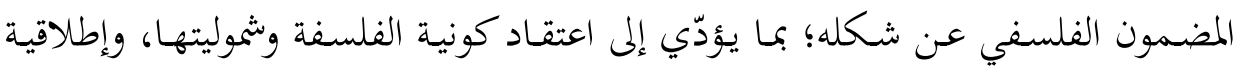

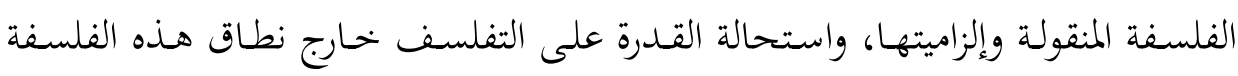

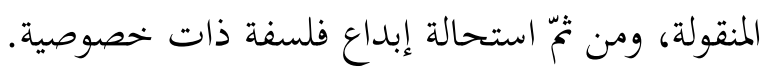

وقد عكف طه عبد الرحمن، في جملة إنتاجه الفكري، على إماطة العوائق عن حركة

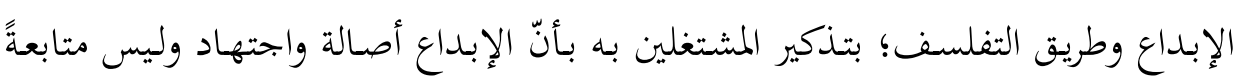

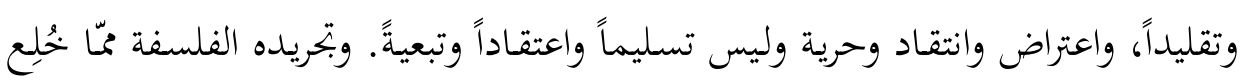

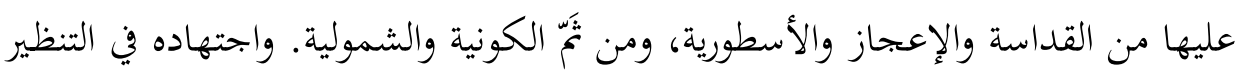

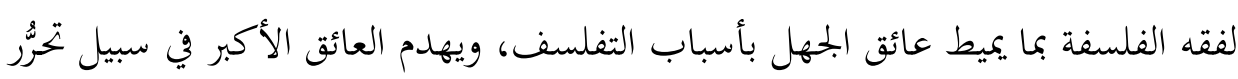

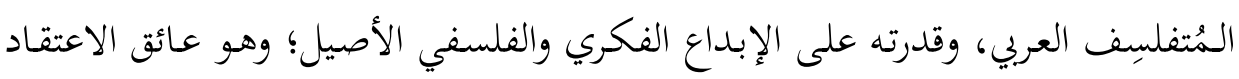

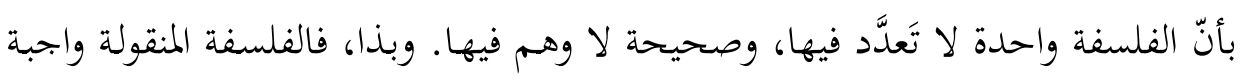

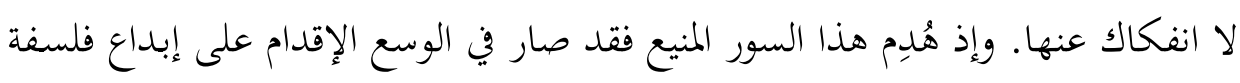
ذات خصوصية.

وقد تصدّى طه عبد الرحمن بكل مسؤولية، وبممة إبداعية وروح تأصيلية، لإبداع

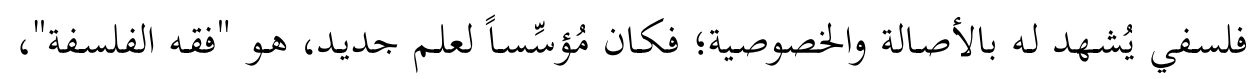

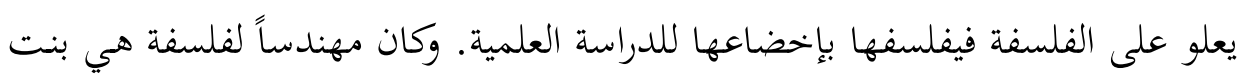

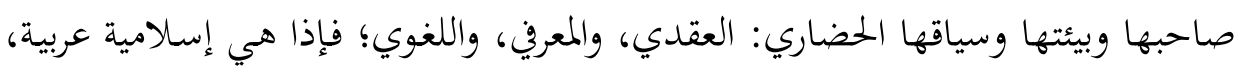

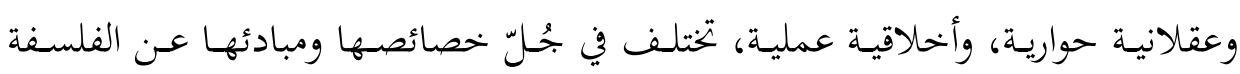

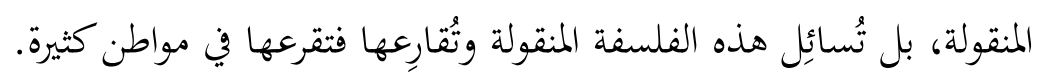
وقد أوصلنا هذا البحث في فكر طه عبد الرحمن إلى نتائج ذات قيمة علمية وفكرية وحضارية بالغة، نُجمِلها في ما يأتي: 
ا. إنّ تحرير العقول من الجهل بأسباب التفلسف، وتخليصها من التفكير الأسطوري

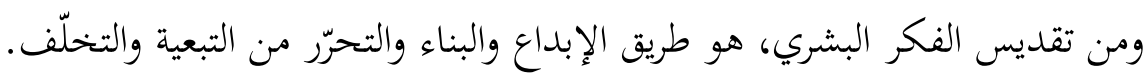

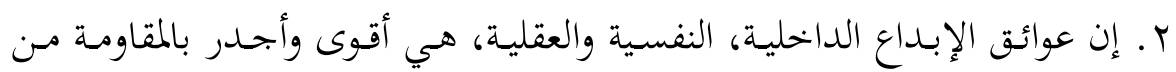
العوائق الخارجية، المادية والاجتماعية.

r. الفكر البشري لا يقينية فيه. وإنّ الفلسفة الكونية هي فكرة أسطورية لا دليل

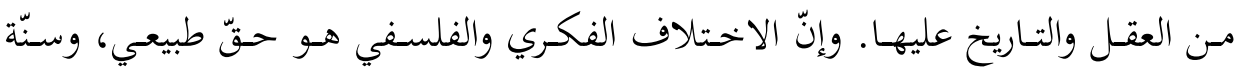
كونية.

ع. إنّ المعرفة والثقافة والفلسفة، كل أولئك يتأثّرّ بالسياق العقدي والمعريف واللغوي

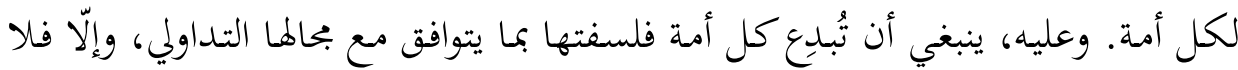

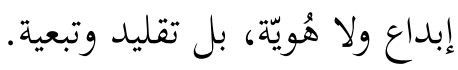

ه. إنّ الاختلاف يقتضـي الحسوار. والحسوار يقتضي المنهجيـة المنطقيـة الاستدلالية،

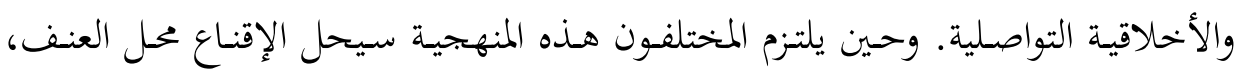
والوفاق محل الحلاف، والألفة محل الفرقة، وتؤول العلاقات بين الأمم إلى مثاقفة بانية.

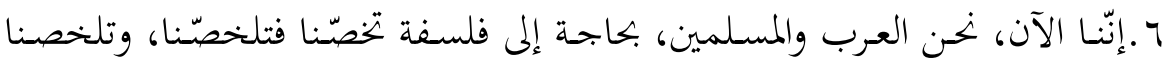

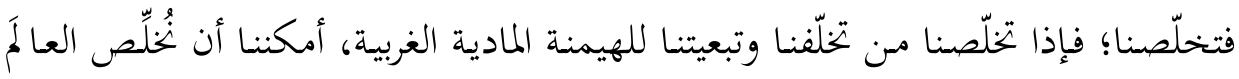
كلّه بفلسفتنا الإسلامية، العقلانية الحوارية، الأخلاقية العملية. 